\title{
Geochemical survey of the Colpitas-Taapaca volcanic-hydrothermal system, northern Chile
}

\author{
Manuel Inostroza (1, 2), Franco Tassi (3, 4), José Sepúlveda (3), Francesco Capecchiacci (3), \\ Andrea L. Rizzo (5) \& Felipe Aguilera $(2,6,7)$
}

\section{ABSTRACT}

This work presents chemical and isotopic $\left(\delta^{13} \mathrm{C}-\mathrm{CO}_{2}, \delta^{13} \mathrm{C}-\mathrm{CH}\right.$ ${ }^{3} \mathrm{He},{ }^{4} \mathrm{He},{ }^{20} \mathrm{Ne},{ }^{40} \mathrm{Ar},{ }^{36} \mathrm{Ar}, \delta^{18} \mathrm{O}$ and $\left.\delta \mathrm{D}\right)$ data on fluid discharges from the Colpitas-Taapaca volcanic-hydrothermal system, located close to the Taapaca Volcanic Complex, with the aim to investigate the physical-chemical conditions of the fluid source and to provide a preliminary evaluation of the geothermic potential of the study area. Colpitas thermal springs (to $56{ }^{\circ} \mathrm{C}$ ) and part of the cold springs $\left(\leq 18^{\circ} \mathrm{C}\right)$ from this area have a Na+ $\mathrm{Na}^{-}$composition and Total Dissolved Solids (TDS) values (from 6,059 to $19,118 \mathrm{mg} / \mathrm{L}$ ). Putre springs also show a $\mathrm{Na}^{+}-\mathrm{Cl}^{-}$composition, TDS values up to $7,887 \mathrm{mg} / \mathrm{L}$, and outlet temperatures from 21 to $31{ }^{\circ} \mathrm{C}$. Colpitas cold springs, with a $\mathrm{Ca}^{2+}-\mathrm{SO}_{4}{ }^{2-}$ composition and relatively low TDS values $(\leq 1,350 \mathrm{mg} / \mathrm{L})$, are likely produced by interaction of shallow water with uprising $\mathrm{H}_{2} \mathrm{~S}$-rich hydrothermal gases. This process is likely also controlling the chemistry of Jurase thermal springs, which have the highest outlet temperatures of the study area (up to $68^{\circ} \mathrm{C}$ ), a $\mathrm{Ca}^{2+}-\mathrm{SO}_{4}{ }^{2-}$ composition and TDS values $\leq 2,355$ $\mathrm{mg} / \mathrm{L}$. Eventually, Las Cuevas springs have temperatures up to 36 ${ }^{\circ} \mathrm{C}$, a $\mathrm{Na}^{+}-\mathrm{HCO}_{3}{ }^{-}$composition and low TDS values $(\leq 1,067 \mathrm{mg} / \mathrm{L})$, typical features of springs related to a shallow aquifer. The $\delta^{18} \mathrm{O}-$ $\mathrm{H}_{2} \mathrm{O}$ and $\delta \mathrm{D}-\mathrm{H}_{2} \mathrm{O}$ values indicate that all waters have a dominant meteoric origin. Enrichments in ${ }^{18} \mathrm{O}$ and $\mathrm{D}$ shown by Colpitas and Putre thermal waters are likely due to steam loss and waterrock interaction, masking a possible direct steam contribution from magmatic degassing. Gas emissions from Colpitas bubbling pools are dominated by $\mathrm{CO}_{2}$, with significant concentrations of $\mathrm{CH}_{4}, \mathrm{H}_{2} \mathrm{~S}$ and $\mathrm{H}_{2}$. The Rc/Ra values (up to 2.04) of Colpitas gases indicate a significant contribution of magmatic to mantle $\mathrm{He}$, whereas the high $\mathrm{CO}_{2} /{ }^{3} \mathrm{He}$ ratios, combined with $\delta^{13} \mathrm{C}-\mathrm{CO}_{2}$ values ranging from -7.66 to $-5.63 \%$ vs. PDB, imply a dominant crustal $\mathrm{CO}_{2}$ source, mostly involving limestone. Estimated temperatures based on the composition of waters and gases from Colpitas are up to $215{ }^{\circ} \mathrm{C}$. Higher temperatures $\left(240{ }^{\circ} \mathrm{C}\right)$ are estimated for Putre thermal waters, although these waters, as well as those from Jurase and Las Cuevas, are too immature for a reliable application of geothermometric techniques. Based on the theoretical reservoir temperature and the measured $\mathrm{Cl}$ total output, the thermal energy released from Colpitas thermal area is estimated at up to $13.9 \mathrm{Mw}$. Such results suggest the occurrence of a promising heat source, possibly related to Taapaca volcanic complex, and encourage the development of future research based on combined geophysical and

(1) Programa de Doctorado en Ciencias, mención Geología, Universidad Católica del Norte, Angamos 0610, Antofagasta, Chile.

(2) Núcleo de Investigación en Riesgo Volcánico - Ckelar Volcanes, Universidad Católica del Norte, Angamos 610, Antofagasta, Chile.

(3) Dipartimento di Scienze della Terra, Università di Firenze, via G. la Pira 4, Firenze, Italia.

(4) CNR-IGG Institute of Geosciences and Earth Resources, via G. la Pira 4, Florence, Italy.

(5) Istituto Nazionale di Geofisica e Vulcanologia (INGV), Sezione di Palermo, Via Ugo La Malfa 153, 90146, Palermo, Italy.

(6) Departamento de Ciencias Geológicas, Universidad Católica del Norte, Angamos 610, Antofagasta, Chile.

(7) Centro de Investigación para la Gestión Integrada de Riesgo de Desastres (CIGIDEN), Avenida Vicuña Mackena 4860, Macul, Santiago, Chile.

Corresponding author e-mail: manuel.inostroza@alumnos.ucn.cl geochemical approaches, in order to provide a reliable evaluation of the geothermal potential of the whole area.

KEY wORDs: Colpitas-Taapaca geothermal system, fluid geochemistry, volcanic-hydrothermal system, geothermal potential.

\section{INTRODUCTION}

The Central Volcanic Zone (CVZ) of the Andean range (Fig. 1a) hosts several active volcanoes and intense hydrothermal activity (Fig. 1b), the latter being mostly related to volcanic edifices (e.g. de SILVA \& FrancIS, 1991; GONZÁLEZ-FERRÁN, 1995).

Geothermal exploration in the northern Chilean sector of CVZ started in the 1960s, in response to the increasing demand of Chile for alternative energy resources, focusing on El Tatio and Puchuldiza areas (LAHSEN, 1969; MAHON, 1974; JiCA, 1979; ElC, 1980; JiCA, 1981) and prosecuted in the 1970s also including Salar de Surire (Trujillo, 1972; Cusicanoui, 1979). Geothermal exploration in this region was suspended in 1982, and started again at the end of 1990s, when governmental regulations promoted a renewed interest for this natural resource, extending the areas of interest to Pampa Lirima, Pampa Apacheta and La Torta de Tocorpuri (Fig. 1b). Other volcanic-hydrothermal systems characterized by a high geothermal potential (e.g. Tacora, Irruputuncu-Olca, Juncalito) were recently recognized (CAPACCIONI et alii, 2011; Aravena et alii, 2016). Notwithstanding the relative high geothermal potential in northern Chile $(\sim 1,300$ MWe; Procesi, 2014), geothermal exploitation actually only started in September 2017 at Pampa Apacheta (Cerro Pabellón plant: $48 \mathrm{MWe}$ ), being delayed respect to the exploration phase due to both the difficult economic situation of the country and the remote location of the geothermal fields. Such a new phase gave a pulse to the investigation of areas where promising hydrothermal system were previously recognized. In this framework, preliminary geophysical and geochemical surveys were carried out at Colpitas, a thermal area located few $\mathrm{km}$ NE of Taapaca Volcanic Complex (TVC) in northern Chile, characterized by the occurrence of several thermal springs and large zones showing hydrothermally altered terrains. The results of preliminary surveys (AguiRre et alii, 2011) suggested the possible occurrence of a fluid reservoir with a temperature of $\sim 200{ }^{\circ} \mathrm{C}$.

In this work, we present the results of a detailed geochemical investigation of the chemical and isotopic 


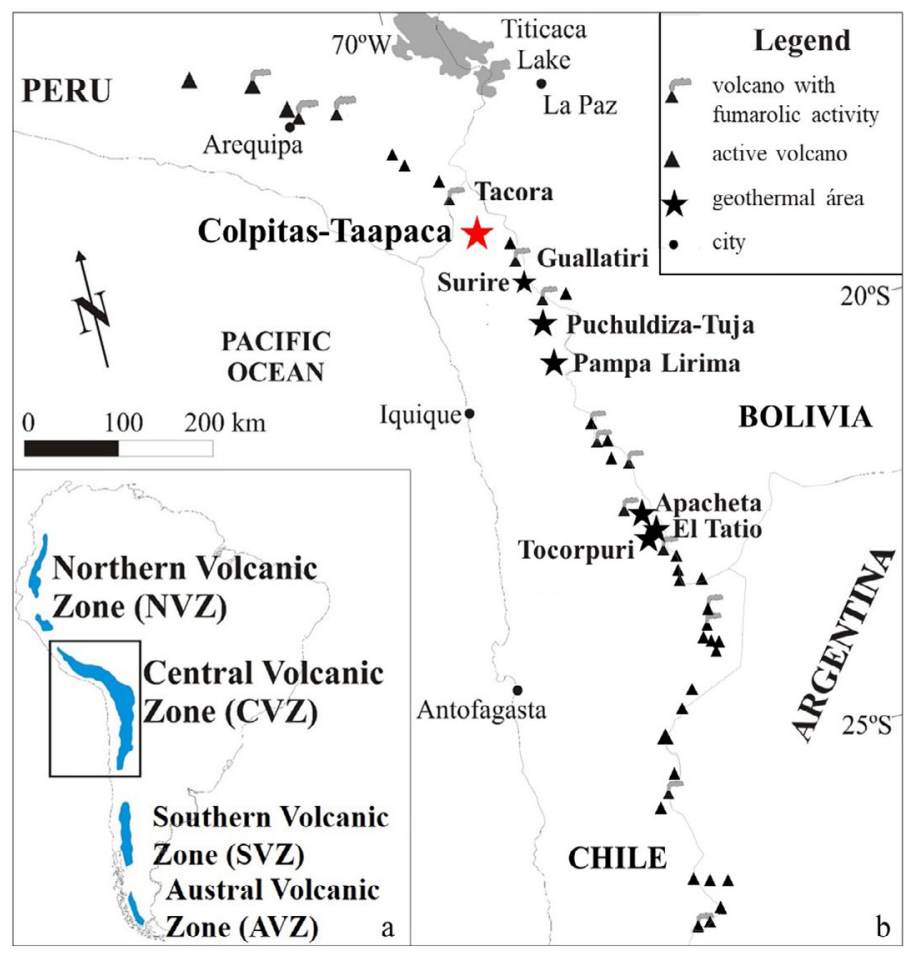

Fig. 1 - (a) Schematic map of Northern, Central, Southern and Austral volcanic zones (NVZ, CVZ, SVZ and AVZ, respectively) of the Andean Range with (b) the location of the main active volcanoes and hydrothermal systems in CVZ.

composition of water and gas samples collected from Colpitas and three thermal areas located south of TVC, namely Putre, Las Cuevas and Jurase. The main aim is to provide insights into (i) the origin of the hydrothermal fluids of the Colpitas-Taapaca system, (ii) the physicalchemical conditions controlling their chemistry at depth, and (iii) an updated evaluation of the geothermal potential.

\section{GEOLOGICAL SETTING AND DESCRIPTION OF THE THERMAL AREAS}

Most hydrothermal systems in the Chilean western side of CVZ (LAHSEN, 1969; TruJillo, 1972; LAHSEN, 1976; Marinovic \& LAHSEN, 1984; TASsi et alii, 2010) are located within NS-NW-trending grabens, which favor the uprising of fluids from reservoirs hosted in upper Oligocene-Pleistocene volcanic rocks or, less frequently, in middle Cretaceous-to-upper Miocene volcanosedimentary sequences (Fig. 2). The Colpitas-Taapaca area is characterized by the occurrence of NS- and NWtrending folds and faults (MuÑoz \& CHARRIER, 1996; GARCíA et alii, 2004, 2012). An upper Oligocene-Miocene volcanosedimentary sequence (Lupica Formation) underlies the Miocene volcanoclastic Huamachuco sequence and the Pliocene-Pleistocene Lauca Formation, a succession of lacustrine and epiclastic deposits interbedded with the 2.7 Ma Lauca Ignimbrite (KöTT et alii, 1995; WÖRNER et alii, 2000; García et alii, 2004). The youngest deposits consist of a series of Pliocene-Pleistocene fluvio-lacustrine gravels, sandstones and siltstones (Visviri Formation; GARCía et alii,
2012). TVC (Fig. 2) was regarded as a potentially active long-lived volcanic system (1.5 Ma-Holocene; CLAVERo et alii, 2004). Four main stages of volcanic activity were here recognized, being characterized by: (i) the emission of andesitic lavas from the northern flank (Stage I); (ii) a steep-sided lava-dome complex, block-and-ash flow and lahar deposits on the northern and eastern flank of the volcanic edifice (Stage II; 1.5-0.5 Ma); (iii) dacitic lavas, domes and associated block-and-ash flow deposits on the central part, southwestern and eastern flanks (Stage III; 0.5-0.47 Ma); iv) Late Pleistocene-Holocene activity (Stage IV: $0.45 \mathrm{Ma}$ to $\sim 2.2 \mathrm{ka}$ ), characterized by the extrusion of voluminous dacitic domes and the occurrence of numerous block-and-ash flows, blasts, fallouts, lahars and both primary and secondary pyroclastic flows on the southern flank (Clavero et alii, 2004). Putre, the main village in this zone of Chilean Altiplano, is built on the top of Taapaca pyroclastic deposits (Fig. 2), some younger than $8 \mathrm{ka}$ (CLAVERo et alii, 2004). The temporal evolution of volcanic activity was marked by a migration (4-5 km) of the main eruptive vents towards SSW (Концвасн \& LOHNERT, 1999; CLAVERo et alii, 2004).

The Colpitas thermal springs (Fig. 3a) are hosted within a flat valley, located $30 \mathrm{~km} \mathrm{NE}$ of Putre village and $17 \mathrm{~km} \mathrm{NE}$ of TVC (Figs. 1 and 2), and are affected by intense hydrothermal alteration. Thermal discharges with a vigorous gas bubbling and presence of polychromatic algae occur in two sectors in the valley at altitudes ranging from 4,130 to $4,170 \mathrm{~m}$ a.s.l. Kaolin and silica sinter deposits (amorphous silica/opal-A, quartz, cristobalite) were reported to occur south of the thermal area, whilst salt (e.g. halite, ulexite) and calcite deposits were observed along Colpitas river, which is the main outflow of the thermal discharges (AguiRre et alii, 2011).

Las Cuevas springs (Fig. 3b), which consist of small water pools representing a local touristic attraction, are located $10 \mathrm{~km}$ SE of TVC (Fig. 1) at an altitude of 4,480 $\mathrm{m}$ a.s.l.

Putre thermal springs (Fig. 3c) are located $11 \mathrm{~km} \mathrm{SW}$ of TVC and $2 \mathrm{~km}$ E of Putre village (Fig. 2) at an altitude of 3,770 $\mathrm{m}$ a.s.l. Sinter deposits and stepped morphology mark the whole emission area.

Jurase thermal springs (Fig. 3d) are located at an altitude of 4,060 m a.s.l., $12 \mathrm{~km} \mathrm{~S}$ of TVC and $5.5 \mathrm{~km}$ $\mathrm{E}$ of Putre village (Fig. 2), inside an area characterized by strong hydrothermal alteration, sinter deposits and abundant polychromatic algae (Healy, 1968; TruJiLlo, 1972; LAHSEN; 1976).

\section{SAMPLING AND ANALYTICAL METHODS}

WATER AND GAS SAMPLING

Gas and water samples from cold and thermal springs from Colpitas, Putre, Jurase and Las Cuevas areas were collected in November 2018 and May 2019.

Waters were sampled in high-density polyethylene (HDPE) bottles, as follows: 2 samples filtered at $0.45 \mu \mathrm{m}$ (Millipore ${ }^{\circledR}$ ) and acidified $(1 \%)$ with ultrapure $\mathrm{HCl}$ and $\mathrm{HNO}_{3}$ for the analysis of major cations and trace elements, respectively; 1 filtered sample for the analysis of anions; 1 unfiltered sample, collected in dark glass bottle, for the analysis of $\delta^{18} \mathrm{O}$ and $\delta \mathrm{D}$. 


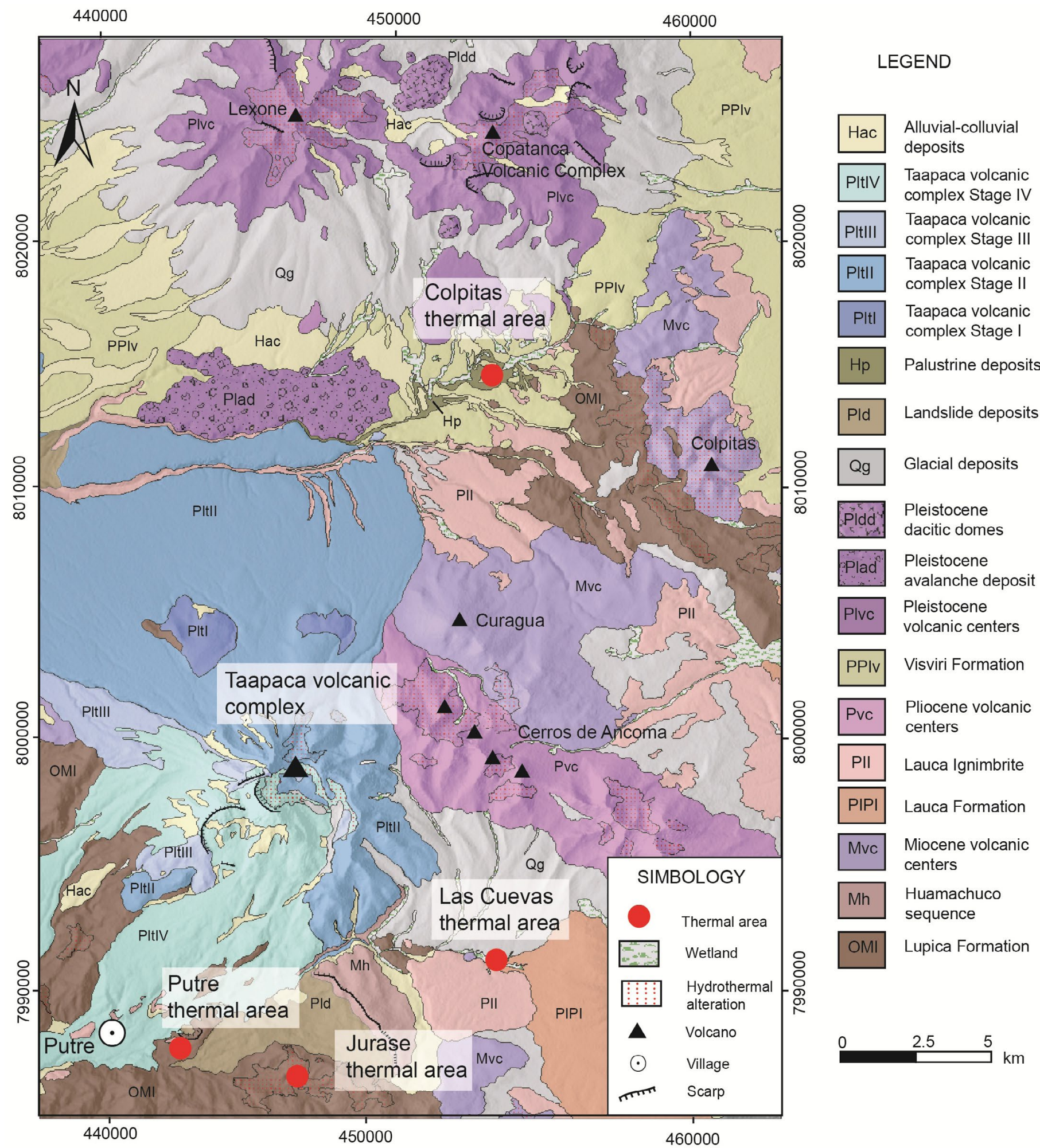

Fig. 2 - Geological map of the region showing the location of Colpitas, Las Cuevas, Putre and Jurase thermal area and Taapaca Volcanic Complex (TVC).

Gas samples from bubbling pools were collected using a funnel up-side-down positioned above the bubbles and connected through tygon tubes to the sampling devices consisting of: (i) a pre-evacuated $60 \mathrm{~mL}$ glass bottle equipped with a Thorion ${ }^{\circledR}$ valve and partially filled with a $4 \mathrm{M} \mathrm{NaOH}$ and $0.15 \mathrm{M} \mathrm{Cd}(\mathrm{OH})_{2}$ alkaline suspension, for the analysis of the chemical gas composition and the ${ }^{13} \mathrm{C}^{12} \mathrm{C}$ ratios in $\mathrm{CH}_{4}$ (MonTEgrossi et alii, 2001); (ii) a preevacuated $60 \mathrm{~mL}$ glass flask equipped with a Thorion ${ }^{\circledR}$ valve for the analysis of the ${ }^{3} \mathrm{He} /{ }^{4} \mathrm{He},{ }^{4} \mathrm{He} /{ }^{20} \mathrm{Ne}$, and ${ }^{40} \mathrm{Ar} /{ }^{36} \mathrm{Ar}$ ratios; (iii) a $12 \mathrm{~mL}$ glass vial equipped with a rubber septum for the analysis and ${ }^{13} \mathrm{C} /{ }^{12} \mathrm{C}$ ratios in $\mathrm{CO}_{2}$. 


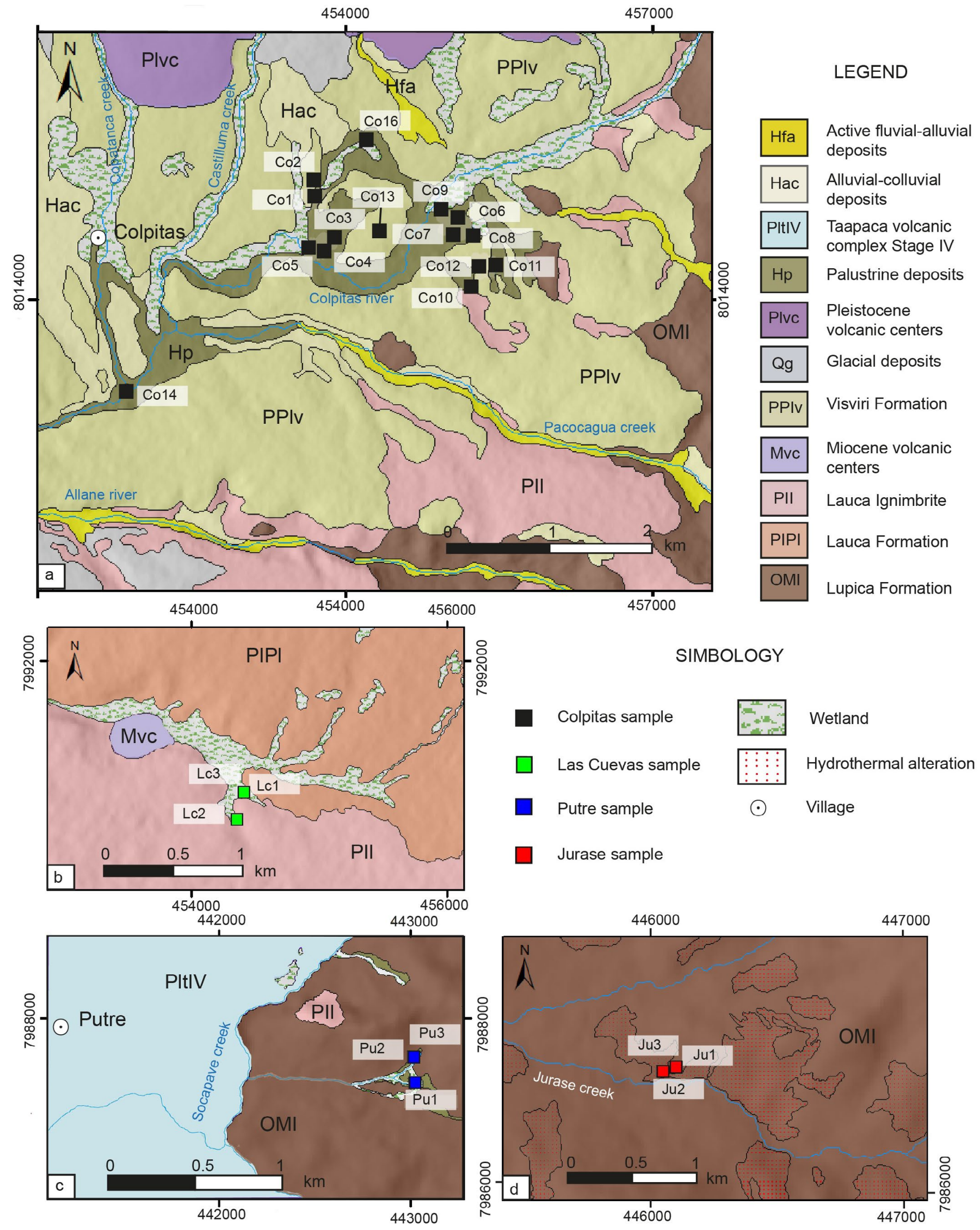

Fig. 3 - Geological maps of the thermal areas studied: (a) Colpitas, (b) Las Cuevas, (c) Putre and (d) Jurase. Sampling sites are reported. 


\section{ChemicAL AND ISOTOPIC ANALYSES OF WATERS}

Water temperature and $\mathrm{pH}$ were measured in situ using a portable instrument. Total alkalinity was analysed by acidimetric titration (AT) using $\mathrm{HCl} 0.01 \mathrm{~N}$. Main anions $\left(\mathrm{F}^{-}, \mathrm{Cl}^{-}, \mathrm{Br}, \mathrm{NO}_{3}^{-}\right.$and $\left.\mathrm{SO}_{4}{ }^{2-}\right)$ and cations $\left(\mathrm{Ca}^{2+}, \mathrm{Mg}^{2+}\right.$, $\mathrm{Na}^{+}, \mathrm{K}^{+}, \mathrm{NH}_{4}^{+}$and $\mathrm{Li}^{+}$) were analysed at the Laboratory of Fluid Geochemistry of the University of Florence (Italy) by ion-chromatography (IC), using Metrohm 761 and Metrohm 861 chromatographs, respectively. The analytical errors for AT and IC were $\leq 5 \%$. Boron was analyzed by molecular absorption spectrometry (MAS; Philips UNICAM) using the Azomethine-H (AH) method (Bencini, 1985). The analytical error for MAS was $\leq 5 \%$. Selected trace elements (As, $\mathrm{Ba}, \mathrm{Fe}, \mathrm{Mn}$ and $\mathrm{Sb}$ ) were analyzed by Inductively Coupled Plasma Optical Emission Spectrometry (ICP-OES) using an Optima 8000 Perkin Elmer spectrometer. The analytical error for ICP-OES was $\leq 10 \%$. The ${ }^{18} \mathrm{O} /{ }^{16} \mathrm{O}$ and ${ }^{2} \mathrm{H} /{ }^{1} \mathrm{H}$ ratios of water samples $\left(\delta^{18} \mathrm{O}-\mathrm{H}_{2} \mathrm{O}\right.$ and $\delta \mathrm{D}-\mathrm{H}_{2} \mathrm{O}$ expressed as $\% o$ vs. V-SMOW) were determined by isotope ratio mass spectrometry (IRMS). Oxygen and hydrogen isotopes measurements were carried out by laser spectroscopy (LGR DT-100 Liquid Water Stable Isotope Analyzer) at the Laboratory of Stable Isotopes of INGV (Palermo, Italy). Analyses were carried out following the protocol of the International Atomic Energy Agency (2009), with analytical error $<1 \%$.

\section{Chemical AND ISOTOPIC ANALYSES OF BUbBLing GASES}

The gas chemical composition was determined at the Laboratory of Fluid Geochemistry of the University of Florence (Italy). The analysis of $\mathrm{N}_{2},\left(\mathrm{Ar}+\mathrm{O}_{2}\right), \mathrm{H}_{2}$ and $\mathrm{He}$ in the headspace of the sampling flasks were carried out by gas chromatography (GC) using a Shimadzu 15A instrument equipped with a Thermal Conductivity Detector (TCD). Argon and $\mathrm{O}_{2}$ were analyzed using a Thermo Focus gas chromatograph equipped with a 30 m long capillary molecular sieve column and a TCD. Methane and light hydrocarbons were analyzed by GC using a Shimadzu 14A instrument equipped with a Flame Ionization Detector (FID) and a $10 \mathrm{~m}$ long stainless-steel column packed with Chromosorb PAW 80/100 mesh coated with 23\% SP 1700 (VASELLI et alii, 2006). The analytical error for the GC analysis was $\leq 10 \%$. Liquid and solid phases from the alkaline suspension were separated by centrifugation to carry out the analyses of $\mathrm{CO}_{3}{ }^{2-}$ (deriving from $\mathrm{CO}_{2}$ dissolution) by AT (using $\mathrm{HCl}$ $0.5^{3} \mathrm{~N}$ and a Metrohm Basic Titrino), and $\mathrm{SO}_{4}{ }^{2-}$ (deriving from $\mathrm{H}_{2} \mathrm{~S}$ trapped as $\mathrm{CdS}$ and dissolved/oxidized with $\mathrm{H}_{2} \mathrm{O}_{2}$ ) by IC (Methrom 761) (MonTEgrossi et alii, 2001).

The ${ }^{13} \mathrm{C} /{ }^{12} \mathrm{C}$ ratio in $\mathrm{CO}_{2}$ and $\mathrm{CH}_{4}\left(\mathrm{~d}^{13} \mathrm{C}-\mathrm{CO}_{2}\right.$ and $\mathrm{d}^{13} \mathrm{C}$ $\mathrm{CH}_{4}$ expressed as \%o vs. V-PDB) were analyzed at the Laboratory of Fluid Geochemistry of the University of Florence by cavity ring-down spectroscopy (Picarro G2201-i). A copper trap was connected to the gas inlet in order to remove $\mathrm{H}_{2} \mathrm{~S}$ (VENTURI et alii, 2019). Analytical error for $\delta^{13} \mathrm{C}-\mathrm{CO}_{2}$ and $\delta^{13} \mathrm{C}-\mathrm{CH}_{4}$ were $0.16 \%$ and $1.15 \%$, respectively.

The ${ }^{3} \mathrm{He} /{ }^{4} \mathrm{He},{ }^{4} \mathrm{He} /{ }^{20} \mathrm{Ne}$ and ${ }^{40} \mathrm{Ar} /{ }^{36} \mathrm{Ar}$ ratios were analyzed at the Noble Gas Isotope Laboratory of INGV (Palermo, Italy) by mass spectrometry. According to the procedure reported by Rizzo et alii (2015, 2016,
2019), $\mathrm{He}, \mathrm{Ne}$ and $\mathrm{Ar}$ were purified from the gas mixture in three distinct ultra-high-vacuum lines and then separately introduced into three dedicated mass spectrometers: (i) a split-flight-tube (GVI Helix SFT) for helium isotopes, (ii) a multicollector (Thermo Helix MC plus) for neon isotopes, and (iii) a multicollector (GVI Helix MC) for argon isotopes. The analytical errors for the determination of ${ }^{3} \mathrm{He} /{ }^{4} \mathrm{He},{ }^{20} \mathrm{Ne}$ and ${ }^{40} \mathrm{Ar} /{ }^{36} \mathrm{Ar}$ were $\leq 1 \%,<0.1 \%$, and $<0.1 \%$ respectively. The ${ }^{3} \mathrm{He} /{ }^{4} \mathrm{He}$ ratios were expressed as $\mathrm{R} / \mathrm{Ra}$, where $\mathrm{R}$ is the ${ }^{3} \mathrm{He} /{ }^{4} \mathrm{He}$ measured in the sample and $\mathrm{Ra}$ is the ${ }^{3} \mathrm{He} /{ }^{4} \mathrm{He}$ ratio in the air and equal to $1.39 \times 10^{-6}$ (Mamyrin \& Tolstikhin, 1984). The measured $\mathrm{R} / \mathrm{Ra}$ values were corrected for air contamination based on the ${ }^{4} \mathrm{He} /{ }^{20} \mathrm{Ne}$ ratios (Poreda \& Craig, 1989), as follows:

$\mathrm{Rc} / \mathrm{Ra}=[(\mathrm{R} / \mathrm{Ra})-\mathrm{r})] /(1-\mathrm{r})$

where $\mathrm{r}=\left({ }^{4} \mathrm{He} /{ }^{20} \mathrm{Ne}\right)_{\text {air }} /\left({ }^{4} \mathrm{He} /{ }^{20} \mathrm{Ne}\right)_{\text {meas }}$, the $\left({ }^{4} \mathrm{He} /{ }^{20} \mathrm{Ne}\right)$ ratio that in the atmosphere $(0.318$; OzIma \& Posodek, $1983)$ and the $\left({ }^{4} \mathrm{He} /{ }^{20} \mathrm{Ne}\right)_{\text {meas }}$ ratio that measured in the gas sample.

\section{RESULTS}

\section{Chemical and isotopic $\left(\delta^{18} \mathrm{O}-\mathrm{H}_{2} \mathrm{O}\right.$ and $\left.\delta \mathrm{D}-\mathrm{H}_{2} \mathrm{O}\right)$ composition OF WATERS}

Sample location (UTM coordinates in WGS84, Zone 19), altitude ( $\mathrm{m}$ a.s.l.), $\mathrm{pH}$, temperature $\left({ }^{\circ} \mathrm{C}\right)$, chemical $(\mathrm{mg} / \mathrm{L})$ and isotopic composition of waters are reported in Table 1. The outlet temperatures of Colpitas waters range from 11 to $56^{\circ} \mathrm{C}$, whereas their $\mathrm{pH}$ values are from 3.13 to 9.15 . Jurase waters have outlet temperatures up to $68{ }^{\circ} \mathrm{C}$ and $\mathrm{pH}$ values from 6.62 to 71.9 , whereas Putre waters have lower temperatures (from 21 to 39 ${ }^{\circ} \mathrm{C}$ ) and a similar range of $\mathrm{pH}$ values (from 6.35 to 7.92 ). Eventually, the outlet temperatures and the $\mathrm{pH}$ values of Las Cuevas waters are from 11 to $36^{\circ} \mathrm{C}$ and from 7.32 to 9.48 , respectively.

Colpitas thermal waters, as well as Co5, Co12 and Co14 cold waters, show a Na+- $\mathrm{Cl}^{-}$composition (Fig. $4 \mathrm{a}, \mathrm{b}$ ) and relatively high TDS values (up to $19,118 \mathrm{mg} / \mathrm{L}$ ), whereas $\mathrm{Co} 1, \mathrm{Co} 2$ and $\mathrm{Co} 13$ cold waters have a $\mathrm{Ca}^{2+}$ $\mathrm{SO}^{2-}$ composition and lower TDS values (from 1,166 to $1,350 \mathrm{mg} / \mathrm{L})$. Putre thermal waters are similar to those from Colpitas, having a Na+ $\mathrm{Cl}^{-}$composition (Fig. 4a,b) and TDS values from 7,225 to 7,887 mg/L. Jurase waters, notwithstanding their high outlet temperatures, have a $\mathrm{Ca}^{2+}-\mathrm{SO}_{4}{ }^{2-}$ composition (Fig. 4a,b) and relatively low TDS values $(\leq 2,355 \mathrm{mg} / \mathrm{L})$. Las Cuevas thermal water have a $\mathrm{Na}^{+}-\mathrm{Cl}^{-}$composition (Fig. 4a,b), although its TDS value $(1,067 \mathrm{mg} / \mathrm{L})$ is significantly lower than those of the $\mathrm{Na}^{+}-\mathrm{Cl}^{-}$waters from the other thermal areas. Las Cuevas cold spring have a Na$\left(\mathrm{Ca}^{2+}\right)-\mathrm{HCO}_{3}$ - composition and the lowest TDS values of the dataset $(56 \mathrm{mg} / \mathrm{L})$. The $\mathrm{NO}_{3}^{-}$concentrations range from 0.42 to $22 \mathrm{mg} / \mathrm{L}$, with no clear distinction among waters from different areas. On the contrary, most minor and trace chemical species, i.e. $\mathrm{B}, \mathrm{Li}^{+}, \mathrm{NH}_{4}^{+}, \mathrm{Fe}, \mathrm{Sb}, \mathrm{Mn}$, and $\mathrm{As}$, show the highest concentrations in $\mathrm{Na}^{+}-\mathrm{Cl}^{-}$thermal waters (up to $130,31,6.8,1.5,1.4,0.81$, and $0.24 \mathrm{mg} / \mathrm{L}$, respectively), and are significantly lower (1-2 orders of magnitude) in the other water samples. Barium show an opposite 
distribution since its concentrations are higher in Colpitas cold waters and Las Cuevas ones (from 0.16 to $0.23 \mathrm{mg} / \mathrm{L}$ ) and one order of magnitude lower in all thermal waters.

The $\delta^{18} \mathrm{O}-\mathrm{H}_{2} \mathrm{O}$ and $\delta \mathrm{D}-\mathrm{H}_{2} \mathrm{O}$ values of Colpitas water range from $-10.0 \%$ to $-8.7 \%$ and from $-97.7 \%$ to $-94 \%$ o vs. V-SMOW, respectively, whereas that of Putre thermal water (Pu3) is slightly higher $(-8.5 \%$ and $-75.3 \%$ vs. V-SMOW, respectively). On the contrary, those of Jurase and Las Cuevas waters are more negative, ranging from $-14.7 \%$ o to $-13.4 \%$ and from $-111 \%$ o to $-75.3 \%$ vs. V-SMOW, respectively).

\section{CHEMICAL AND ISOTOPIC COMPOSITION OF GASES}

Chemical (in $\mathrm{mmol} / \mathrm{mol}$ ) and isotopic composition $\left(\delta^{13} \mathrm{C}-\mathrm{CO}_{2}, \delta^{13} \mathrm{C}-\mathrm{CH}_{4}, \mathrm{Rc} / \mathrm{Ra},{ }^{4} \mathrm{He} /{ }^{20} \mathrm{Ne}\right.$ and ${ }^{40} \mathrm{Ar} /{ }^{36} \mathrm{Ar}$ ratios $)$ of bubbling gases from Colpitas are reported in Table 2. Gas composition is largely dominated by $\mathrm{CO}_{2}$ (504 to $953 \mathrm{mmol} / \mathrm{mol}$ ), followed by significant concentrations of $\mathrm{N}_{2}$ (31 to $471 \mathrm{mmol} / \mathrm{mol}$ ) and $\mathrm{CH}_{4}(0.13$ to $15 \mathrm{mmol} /$ mol). Hydrogen sulfide, $\mathrm{Ar}$ and $\mathrm{O}_{2}$ have concentrations up to $5.2,9.8$ and $15 \mathrm{mmol} / \mathrm{mol}$, whereas those of $\mathrm{H}_{2}$ and $\mathrm{He}$ are $\leq 0.079$ and $\leq 0.007 \mathrm{mmol} / \mathrm{mol}$, respectively. The sum of light hydrocarbons, consisting of $\mathrm{C}_{2}-\mathrm{C}_{4}$ alkanes and alkenes and $\mathrm{C}_{6} \mathrm{H}_{6}$, is $\leq 0.089 \mathrm{mmol} / \mathrm{mol}$.

The $\delta^{13} \mathrm{C}-\mathrm{CO}_{2}$ and $\delta^{13} \mathrm{C}-\mathrm{CH}_{4}$ values range from $-7.66 \%$ to $-5.63 \%$ and $-27.3 \%$ to $-24.8 \%$ vs. V-PDB, respectively, whereas the $\mathrm{Rc} / \mathrm{Ra}$ values are from 1.29 to 2.04 . The ${ }^{40} \mathrm{Ar} /{ }^{36} \mathrm{Ar}$ ratios are $<303$, being close the atmospheric value (295.5; Ozima \& Posodek 2002).

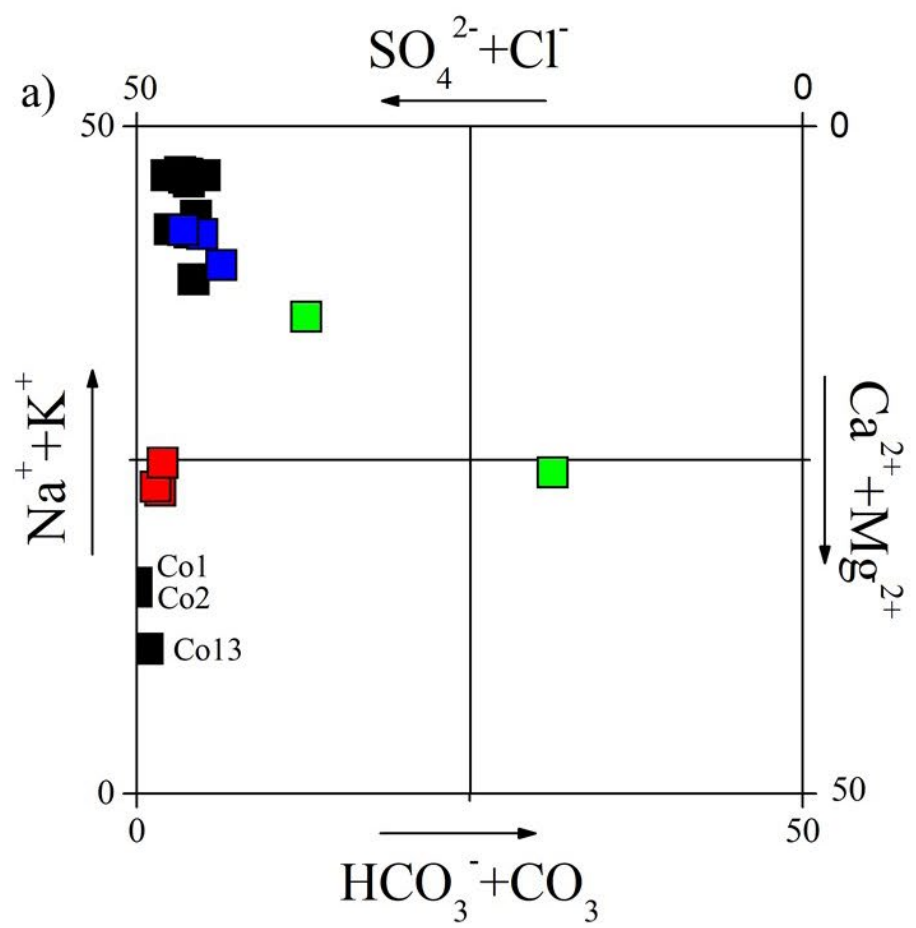

\section{DISCUSSION}

\section{ORIGIN OF WATERS}

According to the most widely accepted classification of thermal waters proposed by Giggenbach (1988) based on the $\mathrm{Cl}^{-}, \mathrm{HCO}_{3}^{-}$and $\mathrm{SO}_{4}{ }^{2-}$ concentrations (Fig. 4b), waters circulating in deep, high-enthalpy geothermal reservoirs show a $\mathrm{Na}^{+}-\mathrm{Cl}^{-}$composition and $\mathrm{Cl}^{-}$concentrations up to ten thousand $\mathrm{mg} / \mathrm{L}$, although in some systems (e.g., Salton Sea, California; Thompson \& Fournier, 1988) $\mathrm{Cl}^{-}$may be as high as $200,000 \mathrm{mg} / \mathrm{L}$. The origin of $\mathrm{Cl}^{-}$in geothermal reservoirs associated with volcanic-magmatic systems and located along convergent plate boundaries, is mostly related to absorption of $\mathrm{HCl}$-rich volcanic vapors. The initially acid aqueous solutions are converted to neutral waters, as consequence of extensive water-rock interaction, causing the progressive enrichment in cations, especially $\mathrm{Na}^{+}$that is leached from host rocks. On the contrary, $\mathrm{Mg}^{2+}$ and, at a lesser extent, $\mathrm{K}^{+}$are incorporated in alteration-clay minerals (Giggenbach, 1997; ReEd, 1997). The chemical compositions of Colpitas and Putre thermal waters are thus consistent with that of a brine diluted, at various degrees, by shallow, low-TDS waters encountered upon approaching the surface. Las Cuevas thermal spring may be related to the same origin, although more strongly affected by dilution. The chemical features of Jurase waters likely derive by the interaction of a shallow aquifer with $\mathrm{CO}_{2}-$ and $\mathrm{H}_{2} \mathrm{~S}$-rich gases produced by steam separation from boiling hydrothermal fluids, as typically occurs above the upflow part of a geothermal system (GiggenBach, 1991; Nicholson, 1993). The lack of significant contribution from the deep brine explains the immaturity of these waters (Fig. 4b). The $\mathrm{Ca}^{2+}-\mathrm{SO}_{4}{ }^{2-}$ Colpitas cold springs,

Fig. 4 - Square diagram (LANGELIER \& Ludwig, 1942) and $\mathrm{HCO}_{3}^{-}-\mathrm{Cl}^{-}-\mathrm{SO}_{4}{ }^{2-}$ ternary diagram (in meq/L) for waters from Colpitas, Jurase, Putre and Las Cuevas thermal areas. Symbols as Fig. 3. 


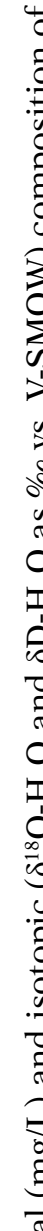

\begin{tabular}{|c|c|c|c|c|c|c|c|c|c|c|c|c|c|c|c|c|c|c|c|c|c|}
\hline & & & & & & & & & & & & & & & & & & & & & \\
\hline & & & $\bar{\tau}$ & & & & & & & & & & & 7 & $\vec{g}$ & & $g$ & אִיא & & & \\
\hline & & & & & $\frac{\mathrm{m}}{\mathrm{m}}$ & & & E & 桑 & 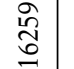 & & & $\vec{S}$ & & & & 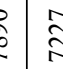 & & & & \\
\hline & & & dre & & $\cong$ & & & $\exists$ & $\cong$ & \pm & \pm & 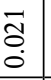 & : & & ఫ్ & & 3 & $\vec{I}$ & & & 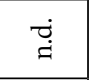 \\
\hline & & & $\overline{0}$ & & తa & & & 0 & 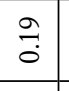 & & o. & & $\begin{array}{l}1 \\
0 \\
0\end{array}$ & 咅 & 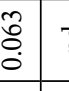 & \pm 3 & 5 & $\Xi$ & & & 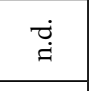 \\
\hline & & & & 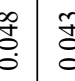 & 苂 & 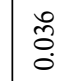 & : & 喜 & $\begin{array}{l}0 \\
\vdots\end{array}$ & : & ֶ̊: & జี & : 8 & 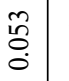 & 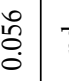 & $\Xi$ & 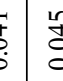 & $\exists$ & & & 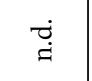 \\
\hline & & & 典 & $\tilde{a}$ & $\cong$ & - & & $\exists$ & $\exists$ & 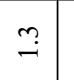 & $\stackrel{2}{2}$ & 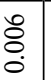 & Ż & Б: & 童 & $\Xi$ & $z$ & 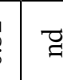 & & & 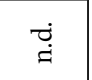 \\
\hline & & & : & $\mid \begin{array}{l}\infty \\
a\end{array}$ & 㕝 & 2 & $\frac{8}{8}$ & $\overline{0}$ & $\underbrace{0}_{0}$ & $\overline{8}$ & $\overrightarrow{0}$ & : & $\stackrel{m}{0}$ & 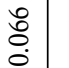 & 营 & $\Xi$ & 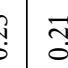 & $\Xi$ & & & تj \\
\hline & & & & & & & & in & $\infty$ & & + & & $\stackrel{n}{N}$ & & $\stackrel{\circ}{\circ}$ & & $=9$ & 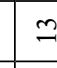 & & & \\
\hline$g$ & & $\stackrel{\circ}{\circ}$ & & a & $\approx$ & $\dot{\sim}$ & & $\bar{\lambda}$ & : & & 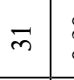 & $\begin{array}{c}\infty \\
\stackrel{\infty}{0}\end{array}$ & in & $\stackrel{\infty}{-}$ & \pm & $E=$ & $\Rightarrow \simeq$ & פת & & & 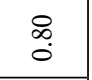 \\
\hline \pm & & & de & 7 & in & 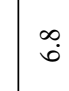 & in & $\begin{array}{l}\infty \\
\text { in }\end{array}$ & $\begin{array}{l}\dot{m} \\
\dot{l}\end{array}$ & in & 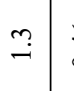 & ; & of & & $\overbrace{0}^{\circ}$ & & $=$ & $\stackrel{-}{\circ}$ & & & a \\
\hline 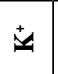 & & & & $\stackrel{\infty}{\approx}$ & $\stackrel{\infty}{{ }_{N}}$ & 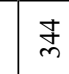 & $\bar{N}$ & $\begin{array}{l}8 \\
8\end{array}$ & 总 & 5 & 5 & ন & אo & $\vec{a}$ & $\simeq$ & & $\overline{3}$ & $\underset{\sim}{\vec{D}}$ & $\infty$ & & $\vec{I}$ \\
\hline 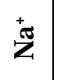 & & & $\underline{\underline{D}}$ & 跑 & $z^{2}$ & 多 & 离 & 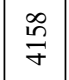 & 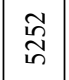 & in & 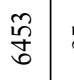 & & $\stackrel{\circ}{8}$ & 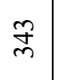 & 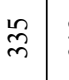 & $\frac{8}{m}$ & 5 & $\frac{\circ}{2}$ & $\sqrt{\sqrt[3]{2}}$ & & $\ddot{g}$ \\
\hline 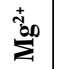 & & & $\approx$ & $\stackrel{\infty}{\alpha}$ & & $\bar{m}$ & $m$ & 出 & F & $\approx$ & $\infty$ & $\therefore$ & $\stackrel{\sim}{2}$ & in & & $8=$ & 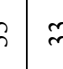 & $\mathrm{m}$ & & & 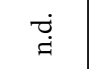 \\
\hline & & & $\stackrel{8}{\circ}$ & 5 & 声 & $\approx$ & $\underset{I}{\mp}$ & $\stackrel{0}{a}$ & 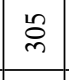 & & 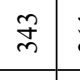 & $\bar{\sim}$ & $\Xi$ & 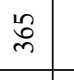 & 串 & 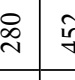 & $=$ & $\stackrel{\circ}{\circ}$ & & & $\tilde{E}$ \\
\hline$e_{n}^{\prime}$ & \pm & & $\overrightarrow{\mathrm{s}}$ & $\$$ & $\approx$ & F & 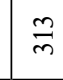 & $\approx$ & 品 & $\mid$ & & \begin{tabular}{l}
8 \\
\hdashline
\end{tabular} & $\frac{\infty}{7}$ & $\begin{array}{l}\substack{\Xi \\
\beth} \\
\end{array}$ & $\stackrel{\mathscr{\%}}{=}$ & 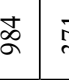 & 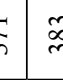 & F & $\nexists$ & $\infty$ & $\vec{g}$ \\
\hline 8 & $\frac{7}{8}$ & & $\underset{\infty}{\infty}$ & 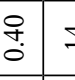 & $\approx$ & $\hat{m}$ & 1 & i & $\bar{m}$ & & D & & $i_{i}$ & 1 & 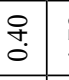 & 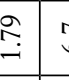 & 58 & \pm & & & 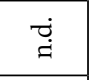 \\
\hline "n & $\stackrel{\vec{n}}{0}$ & & $\vec{f}$ & $:$ & ${ }_{N}^{ \pm}$ & $=$ & $a^{2}$ & $\cong$ & 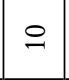 & 8 & $=$ & : & I & og & 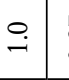 & 5 & 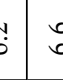 & 3 & f & $\bar{\partial}$ & $\stackrel{d}{J}$ \\
\hline $\bar{J}$ & & 8 & สี่ & 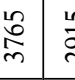 & 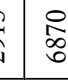 & $\stackrel{\mathscr{O}}{\infty}$ & శ్రి & $\frac{9}{0}$ & 璐 & 1 & 点 & 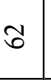 & 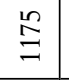 & 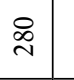 & 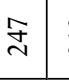 & $\frac{m}{2}$ & $b^{2}$ & $\bar{x}$ & z & & $\vec{d}$ \\
\hline it & & & $\exists$ & 7 & $=$ & 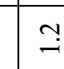 & 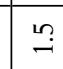 & $\stackrel{\infty}{-\infty}$ & $\stackrel{2}{\rightarrow}$ & & & 9 & $\stackrel{2}{-12}$ & $\infty$ & 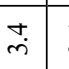 & & S & 90 & m. & ב̇ & ¿ \\
\hline 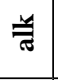 & & & $\stackrel{\text { m }}{m}$ & $g$ & $\underset{\infty}{\stackrel{⿱}{\infty}}$ & $\stackrel{\partial}{ }$ & $\mathscr{\infty}$ & \& & $\stackrel{\vec{g}}{=}$ & & 罣 & & $\underset{\gamma}{\infty}$ & & in & 6 & 8 & F & & $\approx$ & 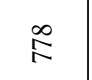 \\
\hline$=$ & & & $\bar{\tau}$ & & $\vec{F}$ & & & in & & & & & & & 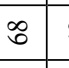 & 8 & $\frac{b}{n}$ & & & & 声 \\
\hline$\underline{z}$ & 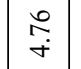 & & 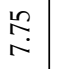 & $\begin{array}{c}0 \\
0 \\
0\end{array}$ & in & $\frac{9}{0}$ & 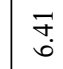 & శ్రి & $\begin{array}{l}1 \\
8 \\
0\end{array}$ & {$\left[\begin{array}{l}n \\
0 \\
0\end{array}\right.$} & 胥 & & $\frac{0}{0}$ & & 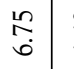 & $\begin{array}{l}0 \\
0 \\
0\end{array}$ & $\begin{array}{l}3 \\
0\end{array}$ & 疋 & 吕 & 承 & న్ \\
\hline & & & & & & & & & & & & & & & 畄 & & & $\frac{2}{2}$ & 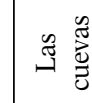 & $\sqrt{\bar{\partial}}$ & 9 \\
\hline & & & 志 & 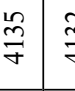 & $\frac{f}{7}$ & $\frac{9}{7}$ & t & $\mid \begin{array}{l}\frac{9}{7} \\
7\end{array}$ & 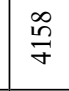 & $\mid \bar{q}$ & & & f & & F & & $n$ & 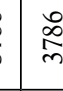 & 7 & F & 拿 \\
\hline & & & 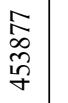 & F & $\begin{array}{l}b^{\prime} \\
\end{array}$ & + & & 第 & & & & & & & & & f & 等 & & & 素 \\
\hline & & 旁总 & & 竎 & 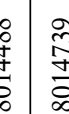 & $\bar{\Phi}$ & & $\frac{1}{5}$ & & & & & & & 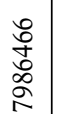 & & & 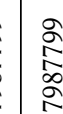 & 高 & 离 & 贾 \\
\hline & & & & & & & & & & & & & & & & & & & & & \\
\hline
\end{tabular}




\begin{tabular}{|c|c|c|c|c|c|c|}
\hline$\frac{\widehat{e}}{\infty}$ & $\underset{\ddot{~}}{\dot{\mu}}$ & ت] & $\stackrel{\sim}{\sim}$ & $\stackrel{\sim}{\sim}$ & & ت্] \\
\hline बे & $\underset{\mu}{\vec{\mu}}$ & تُ & $\stackrel{2}{\circ}$ & t & نூ & ن্d \\
\hline$\widehat{ᄋ}$ & $\underset{\dot{d}}{\mathrm{~d}}$ & $\dot{\vec{g}}$ & స్ & $\stackrel{\infty}{\infty}$ & $\ddot{\check{g}}$ & $\ddot{\check{g}}$ \\
\hline
\end{tabular}

like the Jurase springs, were likely receiving relatively low amount of deep vapors, not able to significantly increase the water temperature.

As far as water isotopes are regarded, both Colpitas and Putre thermal waters (Fig. 5) show a significant enrichment in $\delta^{18} \mathrm{O}-\mathrm{H}_{2} \mathrm{O}$ and $\delta \mathrm{D}-\mathrm{H}_{2} \mathrm{O}$ values respect to $\delta^{18} \mathrm{O}-\mathrm{H}_{2} \mathrm{O}$ and $\delta \mathrm{D}-\mathrm{H}_{2} \mathrm{O}$ values of the local precipitation at $>5,000 \mathrm{~m}$ a.s.l. (СhafFaut et alii, 1998), where the recharge area is likely located considering the altitude of the springs (Table 1). Enrichments in both ${ }^{18} \mathrm{O}$ and D may be caused by (i) steam loss, and (iii) mixing between meteoric and "andesitic" water (TARAN et alii, 1989; GIGGENBACH, 1992). The lack of a significant correlation of $\delta^{18} \mathrm{O}-\mathrm{H}_{2} \mathrm{O}$ and $\delta \mathrm{D}-\mathrm{H}_{2} \mathrm{O}$ values with $\mathrm{Cl}^{-}$concentrations (Fig. 6) suggest that the ${ }^{18} \mathrm{O}$ and D enrichments shown by the Colpitas and Putre thermal waters (Fig. 5) are caused by the first process, which masked a possible steam contribution from magmatic degassing. It is worth noting that the $\mathrm{Ca}^{2+}-\mathrm{SO}_{4}{ }^{2-}$ Jurase and Las Cuevas waters plot on the LMWL, roughly corresponding to their emergence altitude, considering a gradient of $\mathrm{d}^{18} \mathrm{O}-\mathrm{H}_{2} \mathrm{O}$ fractionation with altitude of $2.6 \% \mathrm{~km}$ (PERALTA ARNOLD et alii, 2017). This supports the hypothesis that they are fed by local rainwater interacting with hydrothermal gases emerging at the surface.

Boron and $\mathrm{Cl}^{-}$are considered useful geochemical tracers for geothermal waters (e.g. Nicholson 1993; ARNóRSSON \& ANDRÉSDÓTTIR, 1995), which commonly show $\mathrm{Cl} / \mathrm{B}$ ratios ranging from 10 to 100 (e.g. Ellis \& MAHON, 1977), i.e. consistent with those of Colpitas thermal waters (from 47 to 113) and significantly lower than those of Putre waters (from 175 to 296), the latter being possibly caused by B incorporation in secondary minerals (e.g. ElLIs \& MaHON 1977; Arnórsson \& Andrésdóttir, 1995). Although the $\mathrm{Cl} / \mathrm{B}$ ratios of Jurase and Las Cuevas waters are even lower than those of the Colpitas waters, the relatively low concentrations of these two chemical species $(\leq 280$ and $\leq 7.9 \mathrm{mg} / \mathrm{L}$ for $\mathrm{Cl}$ - and $\mathrm{B}$, respectively) suggest that a significant geothermal contribution is unlike. As shown in Fig. 7, the $\mathrm{NH}_{4}{ }^{+}$concentrations are strictly related $\left(\mathrm{r}^{2}>0.9\right)$ to those of $\mathrm{B}$ and $\mathrm{Cl}$, supporting the hypothesis that they have a common hydrothermal source (e.g., ToNANI, 1970; MARTINI et alii, 1984). Similarly, the concentrations of Fe, $\mathrm{Mn}$, As and Sb (Table 1), which are commonly enriched in hydrothermal fluids (STAufFer \& THOMPSON, 1984; Webster \& Nordstrom 2003; Aiuppa et alii, 2006; KaAsalainen \& Stefánsson, 2012; Wilson et alii, 2012; Göb et alii, 2013), are consistent with those of $\mathrm{B}$ and $\mathrm{NH}_{4}^{+}$. The relatively high concentrations of $\mathrm{Li}^{+}$shown by Colpitas and Putre thermal waters (Table 1) is a typical geochemical feature of mature (or partially mature) hydrothermal fluids, since this element is released during water-rock interactions and is intimately dependent on the temperature (e.g. FoullLac \& MichaRd, 1981; Arehart et alii, 2003). On the contrary, $\mathrm{Ba}$ concentrations in $\mathrm{Na}^{+}-\mathrm{Cl}$ thermal waters (Colpitas and Putre) are lower than those in low-TDS waters (Jurase and Las Cuevas), likely due to calcite precipitation, being this element easily incorporated in carbonate minerals (Yoshida et alii, 2008).

On the whole, the chemical and isotopic characteristics of Colpitas and Putre thermal springs are definitely consistent with those of geothermal fluids, although it is not clear if both these thermal areas are related to a unique, contiguous fluid reservoir, considering the long distance ( $>20 \mathrm{~km}$ ) separating these thermal manifestations. 
The high-altitude $(>5,000 \mathrm{~m}$ a.s.l.) volcanic systems in their surroundings (i.e. Taapaca, Copatanga and Lexone volcanic complexes; Fig. 2) likely represent the areas of meteoric recharge, although detailed investigations aiming

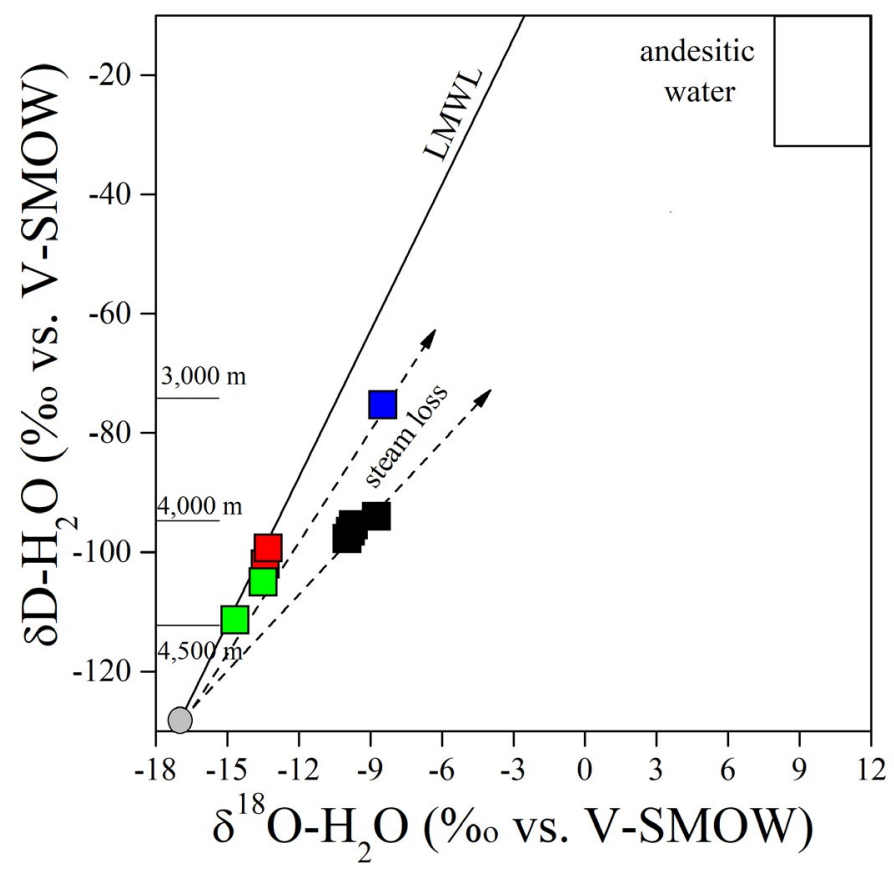

Fig. $5-{ }^{18} \mathrm{O}-\mathrm{H}_{2} \mathrm{O}$ vs. $\delta \mathrm{D}-\mathrm{H}_{2} \mathrm{O}(\% o$ vs. V-SMOW) binary diagram for waters from Colpitas, Jurase, Putre and Las Cuevas thermal areas. Local Meteoric Water Line (LMWL) and the local precipitation at $>5,000 \mathrm{~m}$ a.s.l. (Chaffaut et alii 1998) (grey dot), as well as the "andesitic" field (TARAN et alii, 1989; GIGGENBACH, 1992), are reported. Symbols as Fig. 3.

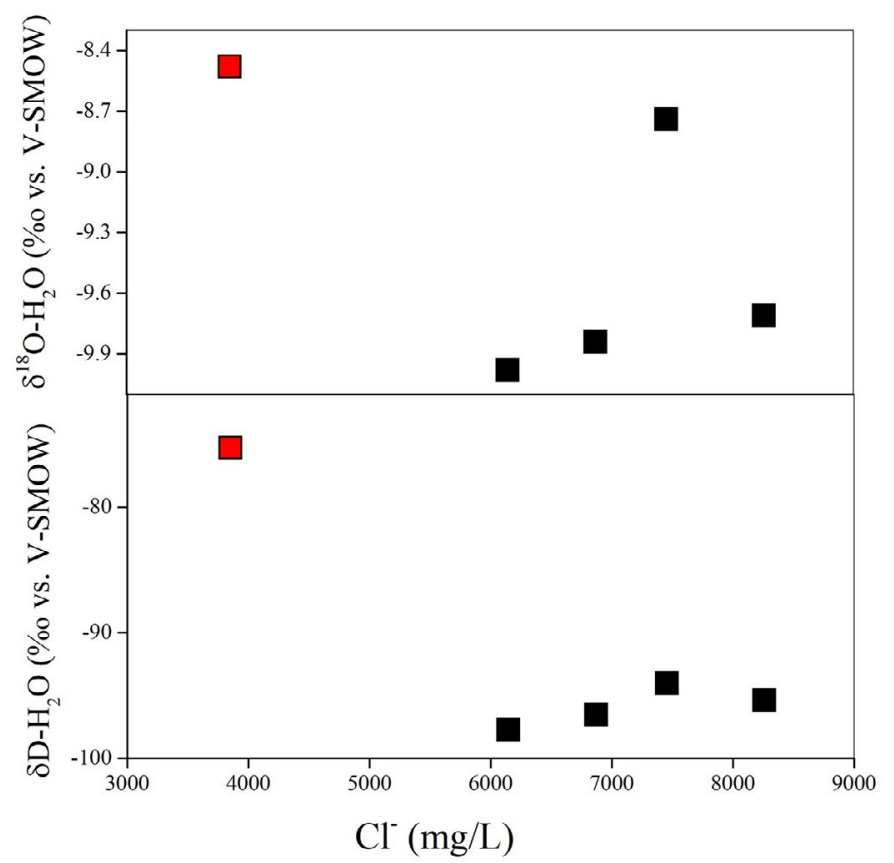

Fig. $6-\delta^{18} \mathrm{O}-\mathrm{H}_{2} \mathrm{O}$ and $\delta \mathrm{D}-\mathrm{H}_{2} \mathrm{O}\left(\% \circ\right.$ vs. V-SMOW) vs. $\mathrm{Cl}^{-}($in $\mathrm{mg} / \mathrm{L})$ binary diagrams for waters from Colpitas and Putre thermal areas. Symbols as Fig. 3. to describe the hydrological and geo-structural settings are needed to support this hypothesis. Uprising geothermal waters are diluted at relatively shallow depth by mixing with low-TDS aquifers fed by local rainwater, the latter receiving a separated steam rich in $\mathrm{H}_{2} \mathrm{~S}$, producing $\mathrm{Ca}^{2+}$ $\mathrm{SO}_{4}{ }^{2-}$ waters (e.g. cold Colpitas waters and Jurase and Las Cuevas thermal springs), with almost negligible direct contribution from the brine.

\section{ORIGIN OF GASES}

Bubbling gases from Colpitas are basically consisting of compounds deriving from (i) air $\left(\mathrm{N}_{2}, \mathrm{Ar}\right.$ and $\left.\mathrm{O}_{2}\right)$ and (ii) a hydrothermal component, dominated by $\mathrm{CO}_{2}$ with significant amounts of $\mathrm{H}_{2} \mathrm{~S}, \mathrm{CH}_{4}$, light hydrocarbons and $\mathrm{H}_{2}$. All gas samples have $\mathrm{N}_{2} / \mathrm{Ar}$ ratios (38.3 to 48.7), i.e in the range of those of air saturated water (ASW: 38 to 42 at 10-70 $\left.{ }^{\circ} \mathrm{C}\right)$ and air $(\sim 80)$, excluding significant contribution from an extra-atmospheric $\mathrm{N}_{2}$ source, as commonly observed in fluids from hydrothermal-volcanic systems in convergent plate boundaries (GIGGENBACH, 1997; SNYDER et alii, 2003). Similarly, the ${ }^{40} \mathrm{Ar} /{ }^{36} \mathrm{Ar}$ ratios (between 295 and 303) are basically consistent with the atmospheric value (295.5; Ozima \& PosodeK, 2002), indicating that radiogenic Ar is negligible. Addition of $\mathrm{O}_{2}$-depleted air to the hydrothermal gases likely occurs at depth, as dissolved phase in the recharging meteoric water. However, air contribution is also related to shallow aquifers, as indicated by the presence of $\mathrm{O}_{2}$ (Table 2), especially in the low-temperature thermal springs (Co5 and Co12).

Hydrogen sulphide, $\mathrm{CH}_{4}$, and $\mathrm{H}_{2}$ are the most common gases in a hydrothermal environment, where reducing conditions are produced by chemical reaction between circulating fluids and embedding rocks (e.g. GigGENBACH 1991; Chiodini \& Marini 1998). Both the $\delta^{13} \mathrm{C}-\mathrm{CH}_{4}$ values (Table 2) and $\mathrm{CH}_{4} /\left(\mathrm{C}_{2} \mathrm{H}_{6} / \mathrm{C}_{3} \mathrm{H}_{8}\right)$ ratios $(\sim 130)$ fit with the values of thermogenic $\mathrm{CH}_{4}$ suggested by BERNARD et

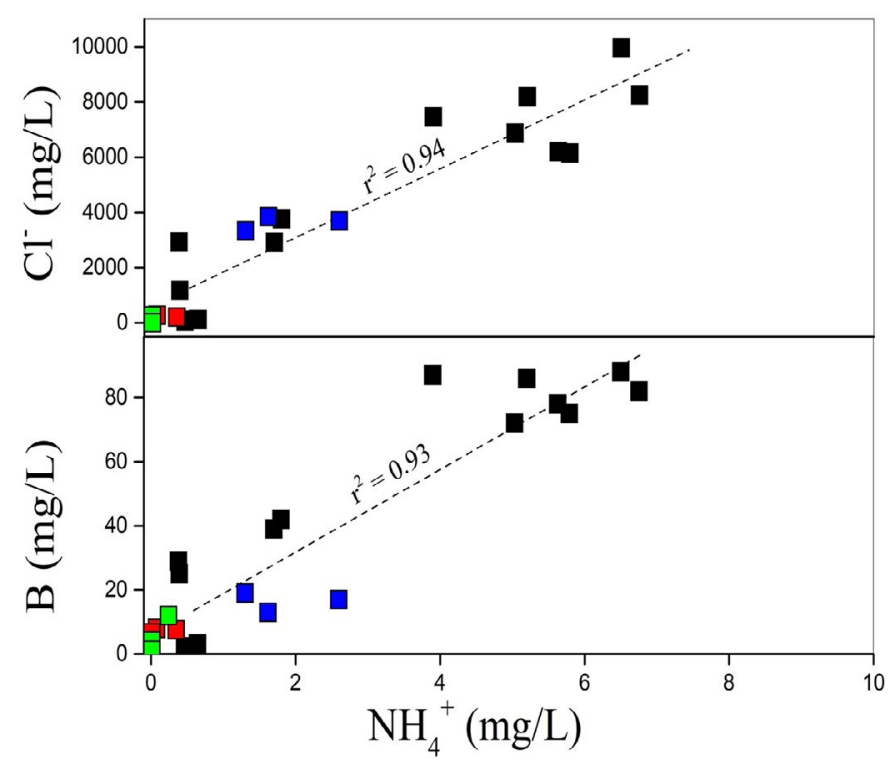

Fig. 7 - Boron and $\mathrm{Cl}^{-}$vs. $\mathrm{NH}_{4}^{+}$(in $\mathrm{mg} / \mathrm{L}$ ) binary diagrams for waters from Colpitas, Jurase, Putre and Las Cuevas thermal areas. Symbols as Fig. 3. 
alii (1978), Schoell (1980) and Whiticar et alii (1986). Thermogenic degradation likely involves organic matter hosted within volcanic-sedimentary sequences in the study area, such as Lupica and Lauca Formations (GARcía et alii, 2004). The origin of $\mathrm{H}_{2} \mathrm{~S}$ is possibly related to the deep heat (magmatic?) source (i.e. $\mathrm{H}_{2} \mathrm{~S}$ formed by reduction of magmatic $\mathrm{SO}_{2}$ ), although further geochemical evidences (e.g. $\mathrm{d}^{34} \mathrm{~S}-\mathrm{H}_{2} \mathrm{~S}$ values, not available for the present study) are needed to discriminate different potential S-sources.

The $\delta^{13} \mathrm{C}-\mathrm{CO}_{2}$ values $(-7.66 \%$ to $-5.63 \%$ vs. V-PDB) are in the range of mantle $\mathrm{CO}_{2}$ (Rollinson, 1993; HoEfs, 1997; Онмото \& Goldhaber, 1997). However, the Rc/Ra values ( 1.3 to $2.0 \mathrm{Ra}$; Table 2$)$, similar to those reported by AgUIRRe et alii (2011), indicate that He resulted from a mixing between crustal (0.01-0.05; PoREDA \& CRAIG, 1989; Hilton et alii, 2002) and mantle fluids probably related to local magmatism. The magmatic/mantle He contribution for Colpitas gases is, indeed, $\leq 25.5 \%$, assuming a MORB-like R/Ra value of $8 \pm 1$ (GRAHAM, 2002), which seems a reasonable assumption based on previous studies carried out in Central and South American volcanic areas (TASSI et alii, 2017; BATISTA CRUZ et alii, 2019). The presence in thermal springs of $\mathrm{Rc} / \mathrm{Ra}$ lower than the expected mantle signature is a common feature in hydrothermal fluids emitted far from the main eruptive vents or in volcanic areas characterized by the waning of magmatic activity at depth (HILTON et alii, 2002; AguILERA et alii, 2012; Benavente et alii, 2016; Lopez et alii, 2018 and references therein). Moreover, it is well known that the South American volcanic arc is built upon mediumhigh thickness of continental crust, which favors the contamination of mantle fluids by radiogenic ${ }^{4} \mathrm{He}$ (Hilton et alii, 1993). Hence, the source regions for $\mathrm{CO}_{2}$ and $\mathrm{He}$ are apparently different. Following the approach proposed by SANO \& MARTY (1995), $\mathrm{CO}_{2}$ contributions from mantle (M), subducted marine limestone (L) and organic-rich sediment (S) can be distinguished based on $\mathrm{CO}_{2} /{ }^{3} \mathrm{He}$ ratios and $\delta^{13} \mathrm{C}-\mathrm{CO}_{2}$ values. As shown in Fig. 8, $\mathrm{CO}_{2}$ in Colpitas gases, in agreement with data of gases from other hydrothermal areas of northern Chile (e.g. El Tatio, Puchuldiza-Tuja and Surire; TAssi et alii, 2010), is mostly deriving from crustal sources (L and S up to $76 \%$ and $24 \%$, respectively; Table 2), whereas $M$ is $<1 \%$, i.e. lower than the typical range for volcanic gases in subduction zones (4-20\%; SANO \& MARTY, 1995). It is worth noting that the evaluation of the percentage of $\mathrm{L}$ may be underestimated with respect to that of $S$, since gases may be affected by changes of $\mathrm{d}^{13} \mathrm{C}-\mathrm{CO}_{2}$ values due to secondary processes, such as multi-step $\mathrm{CO}_{2}$ dissolution and calcite deposition (VENTURI et alii, 2017, and references therein).

\section{GeOTHERMOMETRY}

According to the approach proposed by GIGGENBACH (1988), chemical reactions involving $\mathrm{Mg}$, $\mathrm{Na}$ and $\mathrm{K}$ during water-rock interactions can be used to evaluate the degree of maturity of thermal waters and, if waters attained (or approached) chemical equilibrium, the temperature of their feeding hydrothermal system. As shown in the $\mathrm{Na}^{+} / 400-\mathrm{K}^{+} / 10-\sqrt{\mathrm{Mg}^{2+}}$ ternary diagram (Fig. 9), waters from Las Cuevas and Jurase thermal areas, as well as part of those from the Colpitas cold springs, are too immature for a reliable geothermometric estimation. On the contrary, Colpitas thermal springs seem to approach equilibrium at temperature ranging from 190 to $215^{\circ} \mathrm{C}$, confirming the results obtained by AguirRe et alii (2011). Putre thermal springs plot at the limit between immature and partially equilibrated waters at temperature up to $240{ }^{\circ} \mathrm{C}$, a result that is to be taken with caution given the relatively low degree of maturity of these waters. Further constraints into the chemical-physical conditions of the feeding systems can be obtained by plotting Colpitas and Putre thermal springs in the $\left(10 \mathrm{~K}^{+} /\left[10 \mathrm{~K}^{+}+\mathrm{Na}^{+}\right]\right.$ vs. $10 \mathrm{Mg}^{2+} /\left[10 \mathrm{Mg}^{2+}+\mathrm{Ca}^{2+}\right]$ ) binary diagram (Fig. 10), based on equilibrium temperatures in the $\mathrm{Na}^{+}-\mathrm{K}^{+}$ $\mathrm{Mg}^{2+}-\mathrm{Ca}^{2+}$ system. Considering that most $\mathrm{CO}_{2}$ derives from limestone (Fig. 8), a mineral assemblage involving calcite, dolomite, anhydrite, fluorite, albite, K-feldspar, Ca- and Mg-saponite (CHIodini et alii, 1995) was used to construct the equilibrium curves instead of that adopted by GigGenBACH (1988). At $\mathrm{PCO}_{2}$ values ranging from 1 to 100 bar, the temperatures estimated by combining the $\mathrm{Na}-\mathrm{K}$ and $\mathrm{K}-\mathrm{Mg}$ geothermometers are roughly confirmed.

Estimations of hydrothermal reservoir temperatures are often based on gas equilibria in the $\mathrm{H}_{2}-\mathrm{H}_{2} \mathrm{O}-\mathrm{CO}$ $\mathrm{CO}_{2}-\mathrm{CH}_{4}$ system (e.g. CHIOdini \& Marini 1998). However, $\mathrm{H}_{2} \mathrm{O}$ (vapor) in bubbling gases, especially those having relatively low outlet temperatures such as those of this study, is mostly lost due to condensation, a shallow process that commonly causes the dissolution of $\mathrm{CO}$, a gas species actually not detected in our gas samples. Hence, equilibrium temperatures are tentatively estimated by applying the $\mathrm{CO}_{2}-\mathrm{H}_{2}-\mathrm{Ar}$ geothermometer (GIGGENBACH, 1991). According to this approach, the origin of Ar in the

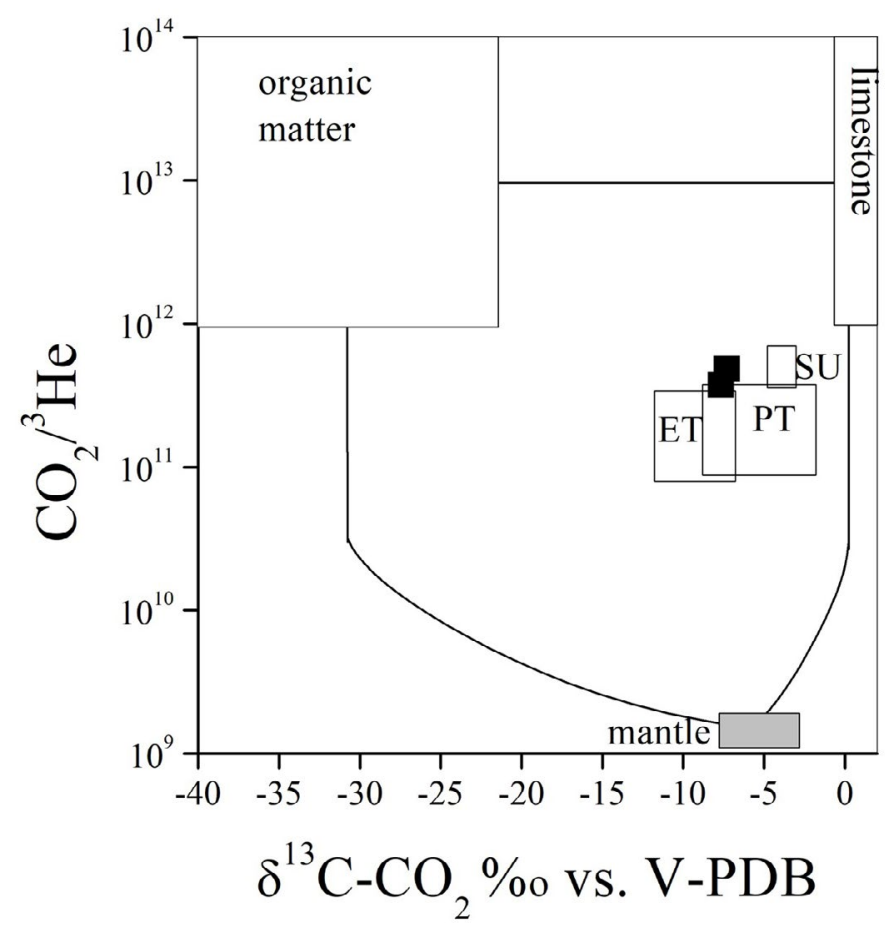

Fig. $8-\mathrm{CO}_{2} /{ }^{3} \mathrm{He}$ vs. $\delta^{13} \mathrm{C}-\mathrm{CO}_{2}$ binary diagram for gases from Colpitas thermal area. End-member compositions of sedimentary (organic)derived carbon (S), calcareous (limestone)-derived carbon (L) and mantle-derived carbon (M) are from Sano and Marty (1995). Data of gases from Surire (SU), Puchuldiza-Tuja (PT), and El Tatio (ET) geothermal areas (TASSI et alii, 2010) are reported for comparison. Symbols as Fig. 3. 
hydrothermal fluid is considered completely atmospheric, i.e. as dissolved gas within air-saturated meteoric water (ASW) recharging the hydrothermal system. Considering that hydrothermal fluids are $\mathrm{O}_{2}$-free, the effect of air contamination at the surface is minimized by subtracting to $\mathrm{Ar}$ concentrations the corresponding $\mathrm{O}_{2} / 22$ ratios (i.e. the $\mathrm{O}_{2} / \mathrm{Ar}$ ratio in air). At redox conditions controlled by a buffer typical for a hydrothermal system (DP; D'Amore \& Panichi, 1980), Colpitas gases seem to be shifted respect to the equilibrium temperature suggested by water chemistry (Fig. 11), possibly due to loss of $\mathrm{H}_{2}$ and/or air addition, i.e. secondary processes typically affecting uprising hydrothermal gases mixing with meteoric aquifers at shallow depth.

Methane can also be involved in geothermometric calculations, assuming that it was controlled by Sabatier reaction, as follows:

$\mathrm{CH}_{4}+2 \mathrm{H}_{2} \mathrm{O} \leftrightarrow \mathrm{CO}_{2}+4 \mathrm{H}_{2}$

Given that $\log \left(f \mathrm{H}_{2} \mathrm{O}\right)=4.9-1820 / \mathrm{T}$ (Giggenbach, 1987) and redox conditions are controlled by the DP buffer, equilibrium curves in liquid and vapor phases for reaction (2) can be computed and plotted in a $\log \left(\mathrm{CH}_{4} /\right.$ $\left.\mathrm{CO}_{2}\right)$ vs. $\log \left(\mathrm{H}_{2} / \mathrm{Ar}\right)$ binary diagram (Fig. 12). Colpitas gases plot far from vapor-liquid equilibrium field, even considering $\mathrm{H}_{2}$ depletion, suggesting lack of equilibrium of reaction (2) due to its slow kinetics. Based on the $\mathrm{d}^{13} \mathrm{C}$ $\mathrm{CH}_{4}$ values (Table 2), a significant addition of biogenic $\mathrm{CH}_{4}$ is indeed to be excluded.

A further opportunity to provide information on the thermodynamic conditions controlling the Colpitas thermal fluids is provided by the $\mathrm{C}_{3} \mathrm{H}_{8}-\mathrm{C}_{3} \mathrm{H}_{6}$ pair (e.g. TARAN \& GiggenBaCh, 2003; TASsi et alii, 2005), which in

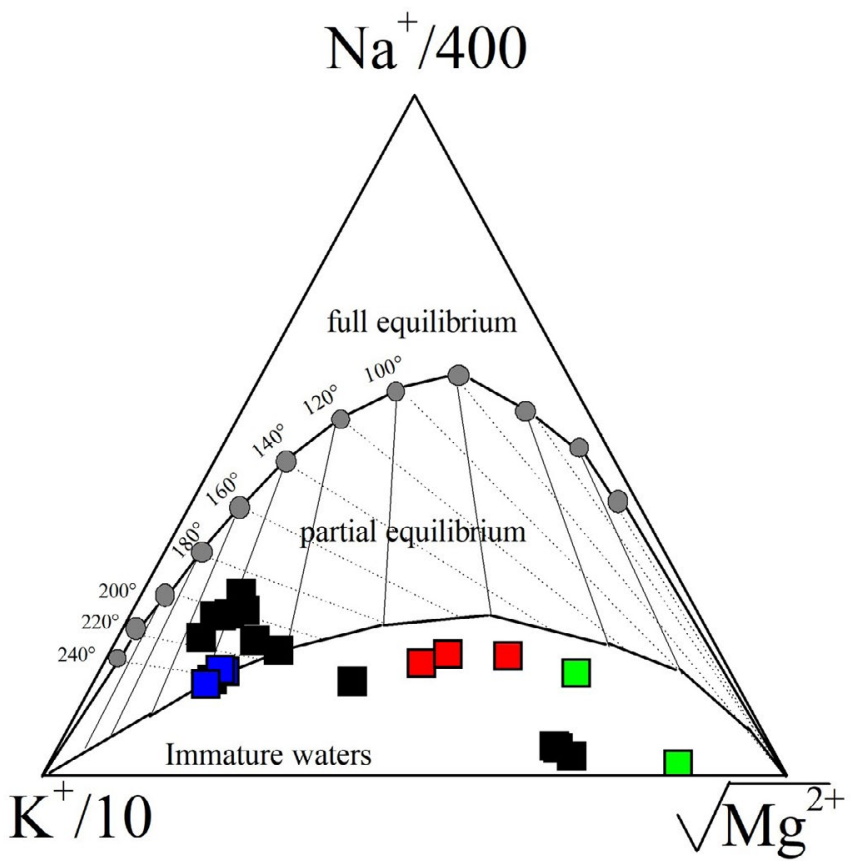

Fig. $9-\mathrm{Mg}^{2+}-\mathrm{Na}^{+}-\mathrm{K}^{+}$ternary diagram GiggENBACH (1988) for waters from Colpitas, Jurase, Putre and Las Cuevas thermal areas. Symbols as Fig. 3.

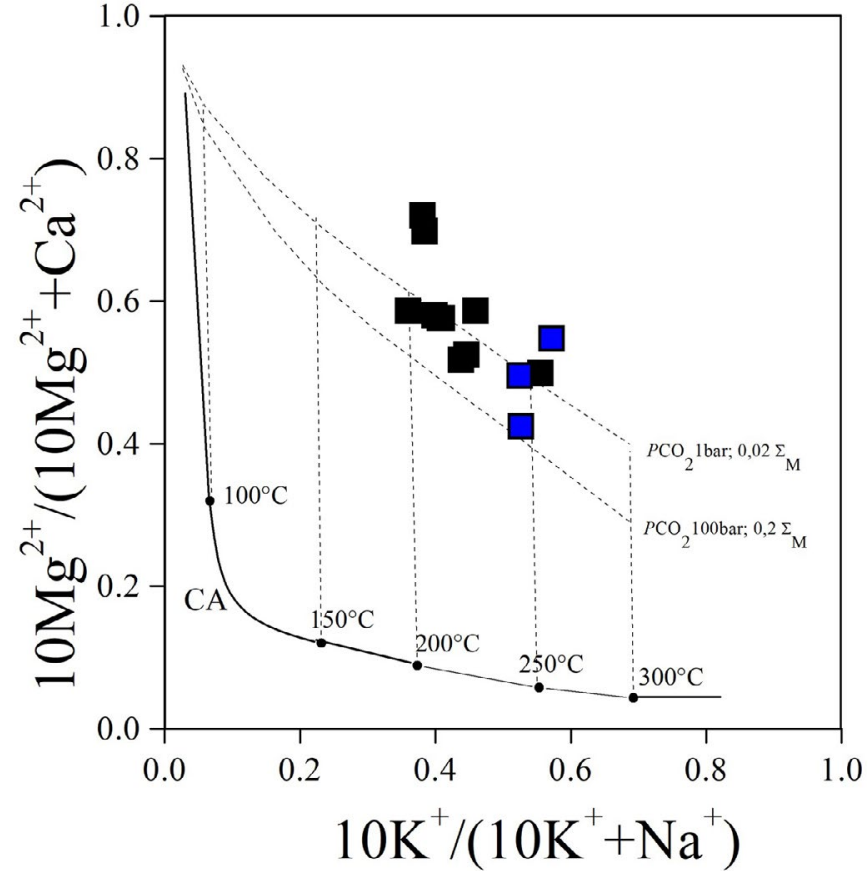

Fig $10-\left[10 \mathrm{~K}^{+} /\left(10 \mathrm{~K}^{+}+\mathrm{Na}^{+}\right)\right]$vs. $\left[10 \mathrm{Mg}^{2+} /\left(10 \mathrm{Mg}^{2+}+\mathrm{Ca}^{2+}\right)\right]$ binary diagram for Colpitas and Putre thermal springs. Equilibrium curves at temperatures ranging from 100 to $300^{\circ} \mathrm{C}$ in presence of different mineral assemblages and salinity values $\left(\Sigma_{\mathrm{M}}: 0.02\right.$ and $\left.0.2 \mathrm{~mol} / \mathrm{L}\right)(\mathrm{GIGGENBACH}$, 1988; CHIODINI et alii, 1995) are reported. Symbols as Fig. 3.

hydrothermal fluids may depend of dehydrogenation reaction, as follows:

$\mathrm{C}_{3} \mathrm{H}_{8} \leftrightarrow \mathrm{C}_{3} \mathrm{H}_{6}+\mathrm{H}_{2}$

The dependence of reaction (3) on temperature and redox conditions $\left(\mathrm{R}_{\mathrm{H}}=\log \left(\mathrm{H}_{2} / \mathrm{H}_{2} \mathrm{O}\right)\right)$ in a vapor phase can be expressed, as follows (CAPACCIONI et alii, 2004):

$\log \left(\mathrm{X}_{\mathrm{C} 3 \mathrm{H} 6} / \mathrm{X}_{\mathrm{C} 3 \mathrm{H} 8}\right)=2.25-\mathrm{R}_{\mathrm{H}}-4,780 / \mathrm{T}(\mathrm{K})$

Assuming that the $\log \left(\mathrm{C}_{3} \mathrm{H}_{6} / \mathrm{C}_{3} \mathrm{H}_{8}\right)$ ratios in vapor are equal to those in the liquid phase (TAssi et alii, 2007), the $\log \left(\mathrm{X}_{\mathrm{C} 3 \mathrm{H} 6} / \mathrm{X}_{\mathrm{C} 3 \mathrm{H} 8}\right)$ values were plotted vs. temperatures in the Na-K-Mg system (Fig. 9), showing $R_{H}$ values at equilibrium temperatures (>-3.9) basically coinciding with those dictated by the DP buffer (Fig. 13).

\section{EVALUATION OF THE GEOTHERMAL POTENTIAL}

All thermal water discharged from the Colpitas springs flow through Colpitas river. Such a hydrological setting allows the application of a simple method, successfully used at Yellowstone (USA; FournIER, 1989) and Domuyo volcano (Argentina; CHIODINI et alii, 2014), to evaluate the thermal energy $\left(Q_{H}\right.$ in $\left.J / s\right)$ released from Colpitas discharges, as follows:

$\mathrm{Q}_{\mathrm{H}}=\left(\mathrm{Q}_{\mathrm{Cl}} / \mathrm{Cl}_{\mathrm{T}}\right) \times \mathrm{H}_{\mathrm{T}}$

where $\mathrm{Q}_{\mathrm{Cl}}$ is the $\mathrm{Cl}^{-}$flux (in $\mathrm{g} / \mathrm{s}$ ) in the river, $\mathrm{Cl}_{\mathrm{T}}$ is the $\mathrm{Cl}^{-}$ concentration on the original hydrothermal liquid, and $\mathrm{H}_{T}$ the enthalpy $(\mathrm{J} / \mathrm{g})$ of the liquid at reservoir temperature. 


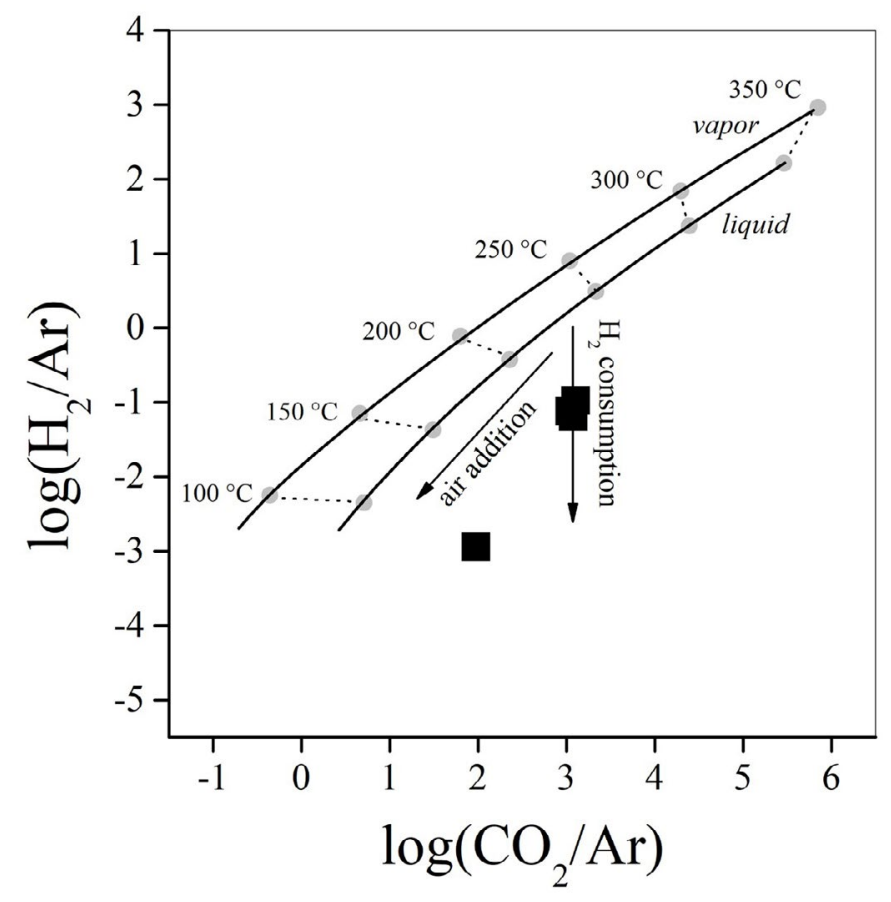

Fig. $11-\log \left(\mathrm{H}_{2} / \mathrm{Ar}\right)$ vs. $\log \left(\mathrm{CO}_{2} / \mathrm{Ar}\right)$ binary diagram for gases from Colpitas thermal area. Equilibrium curves in liquid and vapor phases at temperatures ranging from 100 to $350^{\circ} \mathrm{C}$ and redox conditions controlled by the DP buffer (D'AMORE \& PANICHI, 1980) are reported. Symbols as Fig. 3.

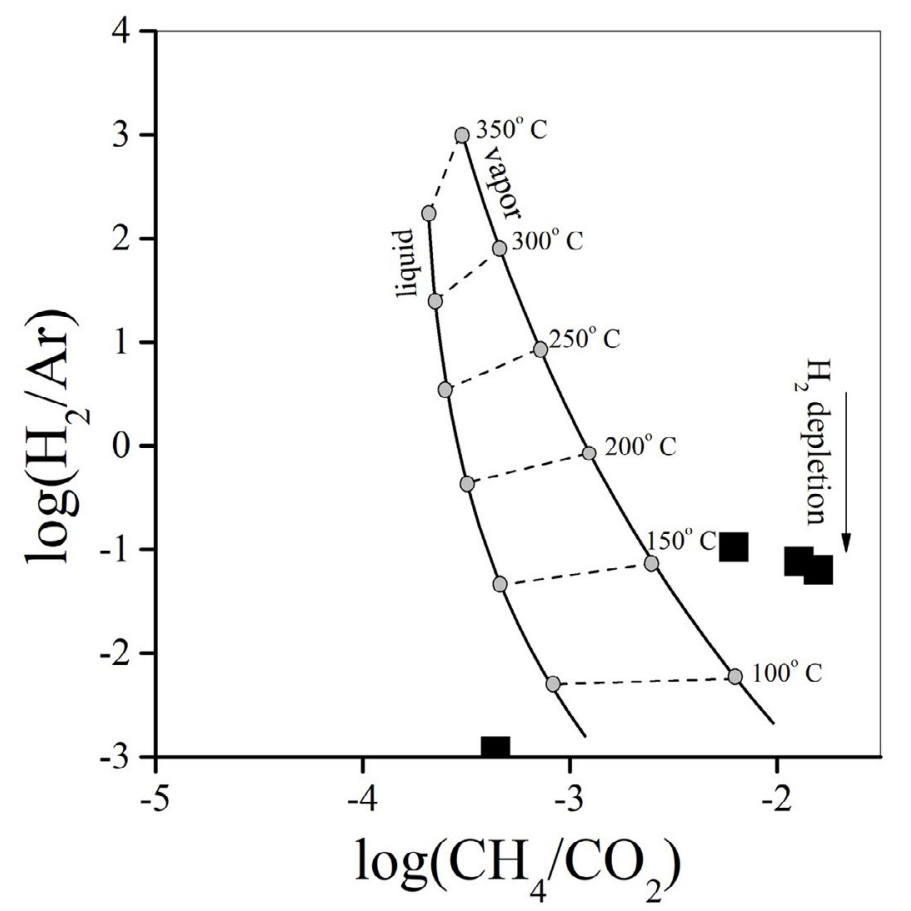

Fig. 12 - $\log \left(\mathrm{CH}_{4} / \mathrm{CO}_{2}\right)$ vs. $\log \left(\mathrm{H}_{2} / \mathrm{Ar}\right)$ binary diagram for gases from Colpitas thermal area. Equilibrium curves in liquid and vapor phases at temperatures ranging from 100 to $350^{\circ} \mathrm{C}$ and redox conditions controlled by the DP buffer (D'AMORE \& PANICHI, 1980) are reported. Symbols as Fig. 3 .
To compute the $\mathrm{Q}_{\mathrm{Cl}}$ value, the flow rate of Colpitas river was measured using the float method (CHIODINI et alii, 2014). According to this approach, the mean velocity of surficial water at a selected site of the river, i.e. where stream and minor rivers converge (sample Co14; Fig. 3a), was estimated by measuring the travel time of a float across a fixed distance. This value is multiplied by the area of the river cross-section at that point. By multiplying the river flow rate $(128 \mathrm{~kg} / \mathrm{s})$ for the $\mathrm{Cl}^{-}$concentration of Co14 $(1,175 \mathrm{mg} / \mathrm{kg})$, the $\mathrm{Q}_{\mathrm{Cl}}$ value is obtained $(150 \mathrm{~g} / \mathrm{s})$. Enthalpy $\left(\mathrm{H}_{\mathrm{T}}=923 \mathrm{~J} / \mathrm{g}\right)$ is computed using the maximum reservoir temperature $\left(\sim 215{ }^{\circ} \mathrm{C}\right)$ estimated by the $\mathrm{Na}-\mathrm{K}$ geothermometer. Assuming the highest measured $\mathrm{Cl}^{-}$ concentration (Co12: $9.97 \mathrm{~g} / \mathrm{kg}$ ) as $\mathrm{Cl}_{\mathrm{T}}$ value, the thermal energy released from Colpitas thermal area is $13.9 \mathrm{Mw}$, a value that is significatively lower compared to those estimated for other geothermal areas in northern Chile, such as El Tatio and Pampa Apacheta (up to 400 MW; Procesi, 2014).

\section{CONCLUSIONS}

Thermal waters discharged from Colpitas and Putre thermal areas show the typical chemical features of geothermal fluids, whereas Las Cuevas and Jurase waters are related to shallow aquifers affected by dissolution of hydrothermal gases. Secondary processes at relatively shallow depth affect the gas phase, especially the main geoindicators (e.g. $\mathrm{H}_{2}, \mathrm{CO}$, and $\mathrm{CH}_{4}$ ), partially masking the chemical features of the deep Colpitas fluids. Geothermometric evaluations based on chemical equilibria

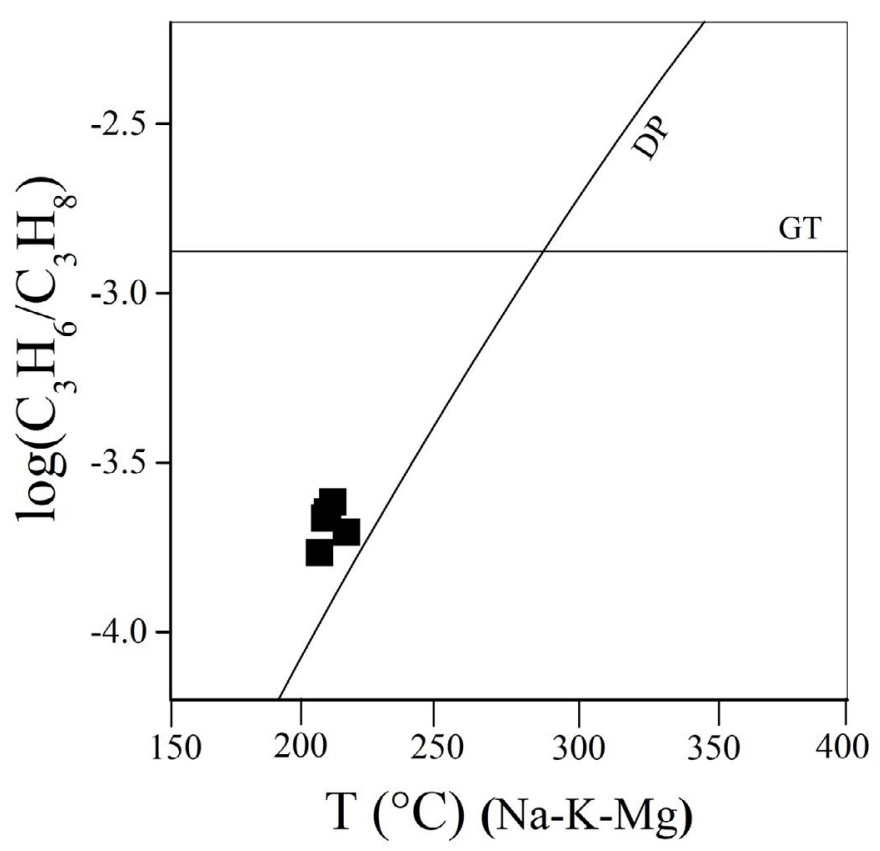

Fig. $13-\log \left(\mathrm{C}_{3} \mathrm{H}_{6} / \mathrm{C}_{3} \mathrm{H}_{8}\right)$ vs. $\mathrm{T}\left({ }^{\circ} \mathrm{C}\right)$ (estimated by the Na-K geothermometer) binary diagram for gases from Colpitas thermal area. Equilibrium curves at redox conditions controlled by DP (D'Amore \& Panichi, 1980) and GT (Giggendach, 1987) buffers are reported. Symbols as Fig. 3. 
in the $\mathrm{Na}-\mathrm{K}-\mathrm{Mg}$ system suggest reservoir temperatures up to $215{ }^{\circ} \mathrm{C}$ for Colpitas waters, whereas those of Putre seem higher (up to $240{ }^{\circ} \mathrm{C}$ ), although the latter result is less convincing since Putre waters were poorly mature. It is not clear if the investigated thermal areas are all related to the local volcanic complex (TVC) as the main heat source, although the $\mathrm{Rc} / \mathrm{Ra}$ values measured in Colpitas gases accounting for up to $25 \%$ of mantle He suggest that magmatic degassing is still active in this system with a reasonable contribution of crustal-derived radiogenic ${ }^{4} \mathrm{He}$.

Thermal energy released from Colpitas, based on the estimated reservoir temperature and $\mathrm{Cl}$ total output, is up to $13.9 \mathrm{Mw}$, a value apparently low compared with those estimated for other geothermal systems in northern Chile. However, further studies aimed to describe the geological and geostructural settings of the area may be helpful to reveal if Colpitas-Taapaca is to be considered a unique geothermal system, allowing a comprehensive evaluation its geothermal potential.

\section{AcKNOWLEDgments}

This work was funded by (1) Comisión Nacional de Investigación Científica y Tecnológica (CONICYT)-PCHA /Doctorado Nacional 12016-21160172, (2) project "Intercambio de Investigadores ChileItalia, convocatoria 2017, Programa de Cooperación Internacional ITAL17002 funded by CONICYT Chile and the Italian Ministry of Foreign Affairs and International Cooperation, (3) Project "CRC-1211 Earth-Evolution at the Dry Limit". The authors wish to express their gratitude to Diego Jaldín, Diego Palacios and Eduardo Campos for their help during fieldtrips and logistics matters. We are also grateful to Mariano Tantillo for noble gas isotope measurements and to Giorgio Capasso, Ygor Oliveri and Aldo Sollami for stable isotopes measurements carried out at INGV (Palermo, Italy). We thank Severina Mamani and Timoteo from Chirigualla hamlet for shared their house with us. An anonymous reviewer and Dr. Domenico Granieri are warmly acknowledged for their useful suggestions and comments that helped the authors to improve the original version of the manuscript.

\section{REFERENCES}

Aguilera F., Tassi F., Darrah T., Moune S. \& Vaselli O. (2012). Geochemical model of a magmatic-hydrothermal system at the Lastarria volcano, northern Chile. Bull. Volcanol., 74(1), 119-134.

Aguirre I., Clavero J., Simmons S., Giavelli A., Mayorga C. \& Soffia J. (2011) - Colpitas-a new geothermal project in Chile. Geoth. Res. T. 35, 1141-1145.

Aiuppa A., Avino R., Brusca L., Caliro S., Chiodini G., D’Alessandro W., Favara R., Federico C., Ginevra W., Inguaggiato S., Longo M., Pecoraino G. \& Valenza M. (2006) - Mineral control of arsenic content in thermal waters from volcano-hosted hydrothermal systems: insights from Island of Ischia and Phlegrean Fields (Campanian Volcanic Province, Italy). Chem. Geol., 229, 313-330.

Aravena D., Muñoz M., Morata D. Lahsen A., Parada M.A. \& Dobson P. (2016) - Assessment of high enthalpy geothermal resources and promising areas of Chile. Geothermics, 59, 1-13.

Arehart G.B., Coolbaugh M.F. \& Poulson S.R. (2003) - Evidence for a magmatic source of heat for the Steamboat Springs geothermal system using trace elements and gas geochemistry. Geoth. Res. T., 27, 12-15.

ARNóRsSon S. \& ANDRÉSDótTIR A. (1995) - Processes controlling the distribution of boron and chlorine in natural waters in Iceland. Geochim. Cosmochim. Ac., 59(20), 4125-4146. https://doi. org/10.1016/0016-7037(95)00278-8

Batista Cruz R.Y., Rizzo A., Grassa F., Bernard Romero R., González Fernández A., Kretzschmar T.G. \& Gómez Arias E.(2019) - Mantle Degassing Through Continental Crust Triggered by Active Faults. The Case of the Baja California Peninsula, Mexico. Geochem. Geophy. Geosy., 20, 1-25. https://doi.org/10.1029/2018GC007987
Benavente O., Tassi F., Reich M., Aguilera F., Capecchiacci F., Gutiérrez, F., Vaselli, O. \& Rizzo, A.L. (2016) Chemical and isotopic features of cold and thermal fluids discharged in the Southern Volcanic Zone between $32.5^{\circ} \mathrm{S}$ and $36^{\circ} \mathrm{S}$ : Insights into the physical and chemical processes controlling fluid geochemistry in geothermal systems of Central Chile. Chem. Geol., 420, 97-113.

Bencini A. (1985) - Applicabilità del metodo dell'Azometina- $H$ alla determinazione del Boro nelle acque naturali. Rendiconti della Societa Italiana di Mineralogia e Petrologia, 40, 311-316.

Bernard B., Brooks J.M., \& SACKETt W.M. (1978) - A geochemical model for characterization of hydrocarbon gas sources in marine sediments. Extended Abstract, Offshore Technology Conference, Houston, Texas, USA. https://doi.org//10.4043/2934-MS

Capaccioni B., Taran Y., Tassi F., Vaselli O., Mangani G. \& Macias J.L. (2004) - Source conditions and degradation processes of light hydrocarbons in volcanic gases: an example from El Chichón volcano (Chiapas State, Mexico). Chem. Geol., 206(1-2), 81-96.

Capaccioni B., Aguilera F., Tassi F., Darrah T., Poreda R.J., \& Vaselli O. (2011) - Geochemical and isotopic evidences of magmatic inputs in the hydrothermal reservoir feeding the fumarolic discharges of Tacora volcano (northern Chile). J. Volcanol. Geoth. Res., 208(34), 77-85.

Chaffaut I., Ooudrain-Ribstein A., Michelot J.L. \& Pouyaud B. (1998) - Précipitations d'altitude du Nord-Chile, origine des sources de vapeur et données isotopiques. Bull. Inst Fr. Etudes Andines, 27, 367-384.

Chiodini G., Frondini F. \& MARINI L. (1995) - Theoretical geothermometers and $\mathrm{pCO}_{2}$ indicators for aqueous solutions coming from hydrothermal systems of medium-low temperature hosted in carbonate-evaporite rocks. Application to the thermal springs of the Etruscan Swell, Italy. Appl. Geochem., 10, 337-346.

CHIODINI G. \& MARINI L. (1998) - Hydrothermal gas equilibria: the $\mathrm{H}_{2} \mathrm{O}$ $\mathrm{H}_{2}-\mathrm{CO}_{2}-\mathrm{CO}-\mathrm{CH}_{4}$ system. Geochim. Cosmochim. Ac., 62(15), 26732687.

Chiodini G., Liccioli C., Vaselli O., Calabrese S., Tassi F., Caliro S. Caselli A., Agusto M. \& D'Alessandro W. (2014) - The Domuyo volcanic system: An enormous geothermal resource in Argentine Patagonia. J. Volcanol. Geoth. Res., 274, 71-77.

Clavero J.E., Sparks R.S.J., Pringle M.S., Polanco E., \& Gardeweg M.C. (2004) - Evolution and volcanic hazards of Taapaca volcanic complex, central Andes of northern Chile. Journal of the Geological Society, 161(4), 603-618.

Cusicanoui H. (1979) - Geochemical study of the Suriri thermal area, Arica province, 1st region. Unpubl. Report, Committee for geothermal energy resources (CORFO), 29 pp. (In Spanish).

D'AMore F. \& PANichi C. (1980) - Evaluation of deep temperatures of hydrothermal systems by a new gas geothermometer. Geochim. Cosmochim. Ac., 44(3), 549-556.

De Silva S.L. \& Francis P.W. (1991) - Volcanoes of the central Andes. Springer-Verlag, Berlin, 216 pp.

Elc-Electroconsult (1980) - Geothermal field of El Tatio: evaluation of the geothermal potential. Unpubl. Report, Committee for geothermal energy resources (CORFO), 13 pp. (in Spanish).

Ellis A.J. \& MAHON W.A.J. (1977) - Chemistry and Geothermal Systems. Academic Press, New York, 392 pp.

Fouillac C. \& Michard G. (1981) - Sodium/Lithium ratio in water applied to the geothermometry of geothermal waters. Geothermics, 10, $55-70$

FOURNIER R.O. (1989) - Geochemistry and dynamics of the Yellowstone National Park hydrothermal system. Ann. Rev. Earth Planet. Sci., 17, 13-53.

García M., Gardeweg M., Clavero J. \& Hérail G. (2004) - Hoja Arica, Región de Tarapacá, escala 1:250,000. Servicio Nacional de Geología y Minería, Carta Geológica de Chile, Serie Geología Básica, 84, Santiago, 151 pp.

García M., Clavero J. \& Gardeweg M. (2012) - Carta Visviri y Villa Industrial, Región de Arica y Parinacota, escala 1:100,000. Servicio Nacional de Geología y Minería. Carta Geológica de Chile, Serie Geología Básica, 135-136, Santiago, 42 pp.

GiggENBACH W.F. (1987) - Redox processes governing the chemistry of fumarolic gas discharges from White Island, New Zealand. Appl. Geochem., 2(2), 143-161. 
GiggENBACH W.F. (1988) - Geothermal solute equilibria. derivation of $\mathrm{Na}-\mathrm{K}-\mathrm{Mg}-\mathrm{Ca}$ geoindicators. Geochim. Cosmochim. Ac., 52(12), 2749-2765.

GiggenBach W.F. (1991) - Chemical techniques in geothermal exploration. In: D'Amore F. (ed.), Application of Geochemistry in Geothermal Reservoir Development. UNITAR/UNDP, Centre on Small Energy Resources, Rome, 119-144.

GIGGENBACH W.F. (1992) - Isotopic shifts in waters from geothermal and volcanic systems along convergent plate boundaries and their origin. Earth Planet Sci. Lett., 113, 495-510.

GIGGENBACH W.F. (1997) - The origin and evolution of fluids in magmatichydrothermal systems. In: Barnes H.L. (ed.), Geochemistry of hydrothermal ore deposits, 3rd Edition. Wiley, New York, pp. 737-796.

Göв S., Loges A., Nolde N., Bau M., Jacob D.E. \& Markl G. (2013) Major and trace element compositions (including REE) of mineral, thermal, mine and surface waters in SW Germany and implications for water-rock interaction. Appl. Geochem., 33, 127-152.

González-Ferrán O. (1995) - Volcanes de Chile. Instituto Geográfico Militar. Santiago, 641 pp.

Graham, D.W. (2002) Noble gas isotope geochemistry of Mid-Ocean Ridge and Ocean Island Basalts: Characterization of mantle source reservoirs. Rev. Mineral. Geochem., 47, 247-317.

Healy J. (1968) - Geological study of hydrothermal systems in the Tarapaca and Antofagasta provinces: preliminary report of Tarapaca Province. Unpubl. Report, Committee for geothermal energy resources (CORFO), 16 pp. (in Spanish).

Hilton, D.R., Hammerschmidt, K., Teufel, S., Friedrichsen, H. (1993) - Helium isotope characteristics of Andean geothermal fluids and lavas. Earth Planet. Sci. Lett., 120(3-4), 265-282.

Hilton D.R., Fischer T.P. \& MARTY B. (2002) - Noble gases and volatile recycling at subduction zones. Reviews in Mineralogy and Geochemistry, 47, 319-370.

Hoefs J. (1997) - Stable Isotope Geochemistry. 4th ed. Springer Verlag, Berlin, $201 \mathrm{pp}$.

JAPAN InTERnational Cooperation Agency (JICA) (1979) - Geothermal power development project in Puchuldiza area. Unpubl. Report, $109 \mathrm{pp}$.

Japan International Cooperation Agency (JICA) (1981) - Report on geothermal power development project in Puchuldiza area. Unpubl. Report, 48 pp.

KaAsalainen H. \& Stefánsson A. (2012) - The chemistry of trace elements in surface geothermal waters and steam, Iceland. Chem. Geol., 330, 60-85.

KötT A., Gaupp R. \& Wörner G. (1995) - Miocene to Recent history of the Western Altiplano in Northern Chile revealed by lacustrine sediments of the Lauca Basin (18 15'-18 40' S/69 30'-69 05' W). Geol. Rundsch., 84(4), 770-780.

Kohlbach I. \& Lohnert E. (1999) - Geological map of Taapaca Volcano and adjacent areas (North Chile), 1:25 000. Thesis, Universität zu Göttingen, Germany, $78 \mathrm{pp}$.

Lahsen A. (1969) - Geology of the area between El Tatio and Cerros de Ayquina. Unpubl. Report, Committee for geothermal energy resources (CORFO), 75 pp. (in Spanish).

LAHSEn A. (1976) - Geothermal Exploration in Northern Chile-Summary. Circum-Pacific energy and mineral resources. Memoir, 25, 169175.

LANGELIER W.F. \& LUDWIG H.F. (1942) - Graphical method for indicating the mineral character of natural waters. J. Am. Water-works Ass., 34, 335-352.

Lopez, T., Aguilera, F., Tassi, F., de Moor, J.M., Bobrowski, N., Aiuppa, A., Tamburello, G., Rizzo, A.L., Liuzzo, M., Viveiros, F., Cardellini, C., Silva, C., Fischer, T., Jean-Baptiste, P., Kazayaha, R., Hidalgo, S., Malowany, K., Lucic, G., Bagnato, E., Bergsson, B., Reath, K. Liotta, M., Carn, S. \& Chiodini, G. (2018) New insights into the magmatic-hydrothermal system and volatile budget of Lastarria volcano, Chile: Integrated results from the 2014 IAVCEI CCVG 12th Volcanic Gas Workshop. Geosphere, 14(3), 983-1007.

MaHon W.A.J. (1974) - The geochemistry of the El Tatio geothermal system. Unpubl. Report, UNDP, New York, 109 pp.

Mamyrin B.A. \& Tolstikhin I.N. (1984) - Helium isotopes in nature. In: FyFE W.S. (Ed.), Development in Geochemistry, Elsevier, Amsterdam, 274 pp.
Martini M., Cellini Legittimo P., Piccardi G. \& Giannini L. (1984) Low temperature manifestations in volcanic areas. Rend. Soc. Ital. Miner. Petrol., 39, 401-405.

Marinovic N. \& Lahsen A. (1984) - Hoja Calama, Región de Antofagasta, escala 1: 250.000. Servicio Nacional de Geología y Minería, Carta Geológica de Chile, 58, 144 pp.

Montegrossi G., Tassi F., Vaselli O., Buccianti A. \& Garofalo K. (2001) - Sulfur species in volcanic gases. Anal Chem., 73, 3709-3715.

Muñoz N. \& CHARRIER R. (1996) - Uplift of the western border of the Altiplano on a west-vergent thrust system, northern Chile. J. S. Am. Earth Sci., 9(3-4), 171-181.

Nicholson K. (1993) - Geothermal fluids: Chemistry and exploration techniques. Springer Verlag, Berlin, 255 pp.

Онмото H. \& Goldhaber M.B. (1997) - Sulfur and carbon isotopes. In: H.L. Barnes (ed.), Geochemistry of Hydrothermal Ore Deposits, John Wiley \& Sons, New York, pp. 517-611.

Ozima M. \& Podosek F.A. (2002) - Noble Gas Geochemistry. Cambridge University Press, Cambridge, 300 pp.

Peralta Arnold Y., Cabassi J., Tassi F., Caffe P.J. \& Vaselli O. (2017) - Fluid geochemistry of a deep-seated geothermal resource in the Puna plateau (Jujuy Province, Argentina). J. Volcanol. Geoth. Res., 338, 121-134.

Poreda R. \& CRAIG, H. (1989) - Helium isotope ratios in circumPacific volcanic arcs. Nature, 338, 473-478. https://doi. org/10.1038/338473a0

Procesi M. (2014) - Geothermal potential evaluation for northern Chile and suggestions for new energy plans. Energies, 7(8), 5444-5459.

Rizzo A.L, Barberi F, Carapezza M.L., Di Piazza A. \& Francalanci L. (2015) - New mafic magma refilling a quiescent volcano: Evidence from He-Ne-Ar isotopes during the 2011-2012 unrest at Santorini, Greece. Geochem. Geophy. Geosy., 16(3), 798-814.

Rizzo A.L., Caracausi A., Chavagnac V., Nomikou P., Polymenakou P., Mandalakis M., Kotoulas G., Magoulas A., Castillo A. \& Lampridou D. (2016) - Kolumbo submarine volcano (Greece): An active window into the Aegean subduction system. Scientific Reports, 6 , 28013. https://doi.org/10.1038/srep28013

Rizzo A.L., Caracausi A., Chavagnac V., Nomikou P., Polymenakou P.N. Mandalakis M., Kotoulas G., Magoulas A., Castillo A., Lampridou D., Marusczak N. \& Sonke J.E. (2019) - Geochemistry of CO-rich gases venting from submarine volcanism: The case of Kolumbo (Hellenic Volcanic Arc, Greece). Front. Earth Sci-Prc., 7, 60. https://doi.org/10.3389/feart.2019.00060

REED M.H. (1997) - Hydrothermal alteration and its relationship to ore fluid composition. In: Barnes H.L. (ed.), Geochemistry of hydrothermal ore deposits, 3d Edition, Wiley, New York, pp. 517611.

Rollinson H. (1993) - Using Geochemical Data. Longman, London, UK, 352 pp.

SANO Y. \& MARTY B. (1995) - Origin of carbon in fumarolic gas from island arcs. Chem. Geol., 119(1-4), 265-274.

Schoell M. (1980) - The hydrogen and carbon isotopic composition of methane from natural gases of various origins. Geochim. Cosmochim. Ac., 44(5), 649-661.

SNyder G., Poreda R., FEHn U. \& Hunt A. (2003) - Sources of nitrogen and methane in Central American geothermal settings: Noble gas and 1291 evidence for crustal and magmatic volatile components. Geochem. Geophy. Geosy., 4(1), 28 pp. https://doi. org/10.1029/2002GC000363

Stauffer R.E. \& Thompson J. M. (1984) - Arsenic and antimony in geothermal waters of Yellowstone National Park, Wyoming, USA. Geochim. Cosmochim. Ac., 48(12), 2547-2561.

Taran Y.A., Pokrovsky B.G. \& EsIKov A.D. (1989) - Deuterium and oxygen-18 in fumarolic steam and amphiboles from some Kamchatka volcanoes: "andesitic waters". Doklady Akademii Nauk SSSR, 304, 440-443.

TARAN Y.A. \& GiggEnBACH W.F. (2003) - Geochemistry of light hydrocarbons in subduction-related volcanic and hydrothermal fluids. Special Publication-Society of Economic Geologists, 10, 61-74.

Tassi F., Martinez C., Vaselli O., Capaccioni B. \& Viramonte J. (2005) - The light hydrocarbons as new geoindicators of equilibrium temperatures and redox conditions of geothermal fields: evidence from El Tatio (northern Chile). Appl. Geochem., 20, 2049-2062. 
Tassi F., Vaselli O., Capaccioni B., Montegrossi G., Barahona F. \& Capra A. (2007) - Scrubbing processes and chemical equilibria controlling the composition of light hydrocarbons in natural gas discharges: An example from the geothermal fields of Salvador. Geochem. Geophy. Geosy., 8, Q05008. https://doi.org/10.1029/2006GC001487

Tassi F., Aguilera F., Darrah T., Vaselli O., Capaccioni B., Poreda R. J., \& Huertas A.D. (2010) - Fluid geochemistry of hydrothermal systems in the Arica-Parinacota, Tarapacá and Antofagasta regions (northern Chile). J. Volcanol. Geoth. Res., 192(1-2), 1-15.

Tassi F., Agusto M., Lamberti C., Caselli A., Pecoraino G., Caponi C., Szentivànyi J., Venturi S. \& Vaselli O. (2017) - The 2012-2016 eruptive cycle at Copahue volcano (Argentina) versus the peripheral gas manifestations: hints from the chemical and isotopic features of fumarolic fluids. Bull. Volcanol., 79, 69. https://doi.org/10.1007/ $\underline{\mathrm{S} 00445-017-1151-7}$

THOMPson J.M. \& FouRnier R.O. (1988) - Chemistry and geothermometry of brine produced from the Salton Sea Scientific Drill Hole, Imperial Valley, California. J. Geophys. Res., 93, B11, 13165-13173.

TonANI F. (1970) - Geochemical methods of exploration for geothermal energy. Geothermics, 2, 492-515.

Trujillo P. (1972) - Study of the thermal manifestations of Suriri. Unpubl. Report. Committee for geothermal energy resources (CORFO), 15 pp. (in Spanish).

Vaselli O., Tassi F., Montegrossi G., Capaccioni B. \& Giannini L. (2006) - Sampling and analysis of volcanic gases. Acta Volcanol., 18, 6576.
Venturi S., Tassi F., Bicocchi G., Cabassi J., Capecchiacci f., Capasso G. VAselli O., Ricci A. \& Grassa, F. (2017) - Fractionation processes affecting the stable carbon isotope signature of thermal waters from hydrothermal/volcanic systems: The examples of Campi Flegrei and Vulcano Island (southern Italy). J. Volcanol. Geoth. Res., 345, 46-57.

Venturi, S., Tassi, F., Mag, F., Cabassi, J., Ricci A., Capecchiacci F., CAPONI C., Nisi B. \& VAselli O. (2019) - Carbon isotopic signature of interstitial soil gases reveals the potential role of ecosystems in mitigating geogenic greenhouse gas emissions: Case studies from hydrothermal systems in Italy. Sci Tot. Environ., 655, 887-898

Webster J.G. \& Nordstrom D.K. (2003) - Geothermal arsenic. In: Welch A.H. \& Stollenwerk K.G. (eds.), Arsenic in Ground Water Springer, Boston, pp. 101-125.

Whiticar M.J., Faber E. \& Schoell M. (1986) - Biogenic methane formation in marine and freshwater environments: $\mathrm{CO}_{2}$ reduction vs. acetate fermentation - isotopic evidence. Geochim. Cosmochim. Ac., 50, 693-709.

Wilson N., Webster-Brown J. \& Brown K. (2012) - The behaviour of antimony released from surface geothermal features in New Zealand. J. Volcanol. Geoth. Res., 247-248, 158-167.

Wörner G., Hammerschmidt K., Henjes-Kunst F., Lezaun J., \& Wilke H. (2000) -Geochronology $\left({ }^{40} \mathrm{Ar} /{ }^{39} \mathrm{Ar}, \mathrm{K}\right.$-Ar and He-exposure ages) of Cenozoic magmatic rocks from northern Chile $\left(18-22^{\circ} \mathrm{S}\right)$ : implications for magmatism and tectonic evolution of the central Andes. Rev. Geol. Chile, 27(2), 205-240.

Yoshida Y, Yoshikawa H. \& Nakanishi T. (2008) - Partition coefficients of $R a$ and $\mathrm{Ba}$ in calcite. Geochem. J., 42, 295-304. 